\title{
Chronic Lyme Disease and Co-infections: Differential Diagnosis
}

\author{
Walter Berghoff*
}

Practice of Internal Medicine, Rheinbach, 53359, Germany

\begin{abstract}
In Lyme disease concurrent infections frequently occur. The clinical and pathological impact of co-infections was first recognized in the 1990th, i.e. approximately ten years after the discovery of Lyme disease. Their pathological synergism can exacerbate Lyme disease or induce similar disease manifestations. Co-infecting agents can be transmitted together with Borrelia burgdorferi by tick bite resulting in multiple infections but a fraction of co-infections occur independently of tick bite. Clinically relevant co-infections are caused by Bartonella species, Yersinia enterocolitica, Chlamydophila pneumoniae, Chlamydia trachomatis, and Mycoplasma pneumoniae. In contrast to the USA, human granulocytic anaplasmosis (HGA) and babesiosis are not of major importance in Europe. Infections caused by these pathogens in patients not infected by Borrelia burgdorferi can result in clinical symptoms similar to those occurring in Lyme disease. This applies particularly to infections caused by Bartonella henselae, Yersinia enterocolitica, and Mycoplasma pneumoniae. Chlamydia trachomatis primarily causes polyarthritis. Chlamydophila pneumoniae not only causes arthritis but also affects the nervous system and the heart, which renders the differential diagnosis difficult. The diagnosis is even more complex when co-infections occur in association with Lyme disease. Treatment recommendations are based on individual expert opinions. In antibiotic therapy, the use of third generation cephalosporins should only be considered in cases of Lyme disease. The same applies to carbapenems, which however are used occasionally in infections caused by Yersinia enterocolitica. For the remaining infections predominantly tetracyclines and macrolides are used. Quinolones are for alternative treatment, particularly gemifloxacin. For Bartonella henselae, Chlamydia trachomatis, and Chlamydophila pneumoniae the combination with rifampicin is recommended. Erythromycin is the drug of choice for Campylobacter jejuni.
\end{abstract}

Keywords: Bartonellosis, Borellia burgdorferi, Chlamydophila pneumoniae, Chlamydia trachomatis, co-infection, Lyme disease, Mycoplasma pneumoniae, treatment, Yersinia enterocolitica.

\section{INTRODUCTION}

In Lyme disease, other infections, whose pathological synergism exacerbate the disease or induce similar clinical manifestations, can exist concurrently. Such concomitant infections are termed co-infections. Co-infections can be transmitted together with Borrelia burgdorferi by tick-bite, and result in multiple infection. Part of co-infections is independent of tick-bite.

The goal of this review was to summarize the more important co-infections completed with some personal experiences and with a short summary on reactive arthritis. Because of the similarity of the clinical symptoms of tularemia, Q fever, parvovirus B19 and Campylobacter jejuni infections to those of Lyme disease a short summary of these infections are also included.

\section{RELEVANT CO-INFECTIONS IN LYME DISEASE}

Co-infections can exacerbate Lyme disease through immune system modulation and are considered to be the major cause for resistance to therapy [1-17]. The importance of

*Address correspondence to this author at the Practice of Internal Medicine, Telemannstrasse D, 53359 Rheinbach, Germany;

Tel: + 492226 2041; Fax: + 492226 2044;

E-mail: dr.w.berghoff@t-online.de co-infections in the disease process, i.e. their pathogenicity compared to Lyme disease, has not been clarified. In cases with double or multiple infections, to determine which infection predominates in the pathological process is difficult. There are substantial overlaps between the clinical symptoms caused by co-infections and Lyme disease. Consequently, an unequivocal assignment of the manifestations of the disease to existing infections might be difficult. The diagnostic difficulties of Lyme disease and co-infections always concern chronic Lyme disease (late Lyme disease, stage III). The synergic-pathological mechanism requires that co-infections are also present in chronic persistent form. Anamnestic consideration of the acute form of co-infections may be helpful to recognize their persistence in the chronic stage.

For the majority of co-infections, as for Lyme disease, laboratory diagnostic tests for indirect pathogen detection, including serological tests and lymphocyte transformation test (LTT, syn. LPT (lymphocyte proliferation test)) are available. Previous infection can be confirmed with serological tests, but a positive serological finding is not proof that the infection causes the current illness. It cannot prove the presence of active infection, and in case of seronegativity it cannot exclude it. Only if the occurrence of positive laboratory findings or their deterioration occur in temporal relationship with the disease state and development assumption 
of chronic disease may be justified e.g. espacialy in cases with previous sero-negativity or negative LTT or significancy lower initial values.

The significant co-infections in Lyme disease are caused by various Bartonella species, primarily Bartonella henselae, by Chlamydia trachomatis, Chlamydophila pneumoniae, Yersinia enterocolitica, and Mycoplasma pneumoniae (Table 1)

\section{CO-INFECTIONS IN LYME DISEASE: OWN EX- PERIENCE}

The frequency of seropositivity and positive LTT of coinfections was evaluated. The laboratory examinations were done in the Institut für Medizinische Diagnostik (IMD), Berlin, Germany. For details of the methods used see reference [34]. The results are illustrated in Table 2. CD57 NK cells are frequently diminished in chronic Lyme disease, but seldom in cases involving only the so called HGE coinfections. The basic principle is that CD57 NK cells can be

Table 1. Co-infections in Lyme Disease

\begin{tabular}{|c|c|c|c|c|}
\hline Disease* & Pathogen & Mode of transmission & Reservoir & IC, EC \\
\hline \multicolumn{5}{|c|}{ Tick-borne co-infections } \\
\hline $\begin{array}{l}\text { HGA (HGE) } \\
\text { HME }\end{array}$ & $\begin{array}{l}\text { Anaplasma phagocytophila } \\
\text { E. chaffeensis }\end{array}$ & $\begin{array}{l}\text { Ticks Ixodes ricinus (Europe) Ixodes } \\
\text { scapularis (USA) }\end{array}$ & $\begin{array}{l}\text { White- footed } \\
\text { mouse (HGA) } \\
\text { Red deer, human } \\
\text { beings (HME) }\end{array}$ & IC \\
\hline Bartonellosis & $\begin{array}{l}\text { Bartonella henselae } \\
\text { (Bartonella quintana, Bartonella } \\
\text { bacilliformis) [18-20] }\end{array}$ & $\begin{array}{l}\text { Bite or scratch wounds of dog or cat } \\
\text { (saliva, claws); cat fleas; lice ( } B \text {. } \\
\text { quintana) [21, 22], tick bite } \\
\text { Others: dust mites, flea bites, flea feces } \\
\text { (oral infection), contact with cats, contact } \\
\text { with dogs (paws, saliva, lice [21], flies, } \\
\text { gadflies, blood transmission, mother-child } \\
\text { transmission [23] }\end{array}$ & $\begin{array}{l}\text { Cats [24-27], } \\
\text { domestic and wild } \\
\text { animals [28] }\end{array}$ & IC \\
\hline $\begin{array}{l}\text { Rickettsiosis Mediterranian } \\
\text { spotted fever }\end{array}$ & $\begin{array}{l}\text { Rickettsia helvetica Rickettsia } \\
\text { conorii }\end{array}$ & Ticks, mites, fleas, lice & Ticks & IC \\
\hline Tularemia & Francisella tularensis & $\begin{array}{l}\text { Mosquitos, gadflies, fleas, lice, mites, } \\
\text { oral, inhalation }\end{array}$ & $\begin{array}{l}\text { Various } \\
\text { vertebrates }\end{array}$ & IC \\
\hline Q fever & Coxiella burnetii & Oral or inhalation & $\begin{array}{l}\text { Cattle, milk, } \\
\text { human beings }\end{array}$ & IC \\
\hline Babesiosis & $\begin{array}{l}\text { Babesia microti, Babesia divergens } \\
{[29,30]}\end{array}$ & $\begin{array}{l}\text { Ixodes ricinus (Europe), Ixodes scapularis } \\
\text { (USA) }[29,30], \text { blood transfusions }[31] \text {, } \\
\text { perinatal }[32,33]\end{array}$ & $\begin{array}{l}\text { Cattle } \\
\text { (other verte- } \\
\text { brates) }\end{array}$ & IC \\
\hline \multicolumn{5}{|c|}{ Other co-infections (not tick-borne) } \\
\hline Mycoplasma infections & Mycoplasma pneumoniae & Droplet infection, humans & Human beings & EC \\
\hline $\begin{array}{l}\text { Chlamydophila pneumoniae } \\
\text { infection }\end{array}$ & Chlamydophila pneumoniae & Droplet infection, person to person & Human beings & IC\&EC \\
\hline $\begin{array}{l}\text { Chlamydia trachomatis infec- } \\
\text { tion }\end{array}$ & Chlamydia trachomatis & Sexual contact & Human beings & IC\&EC \\
\hline Yersiniosis & $\begin{array}{l}\text { Yersinia enterocolitica } \\
\text { Yersinia pseudotuberculosis (USA) }\end{array}$ & Fecal-oral & $\begin{array}{l}\text { Various verte- } \\
\text { brates }\end{array}$ & IC\&EC \\
\hline Parvovirus B19 infection & Human parvovirus B19 & $\begin{array}{l}\text { Respiratory tract: droplet infection, person } \\
\text { to person, during pregnancy, blood trans- } \\
\text { fusion }\end{array}$ & Human beings & IC \\
\hline $\begin{array}{l}\text { Campylobacter jejuni } \\
\text { infection }\end{array}$ & Campylobacter jejuni & $\begin{array}{l}\text { Fecal-oral } \\
\text { Game and domestic animals, particularly } \\
\text { poultry, animal products, contaminated } \\
\text { water }\end{array}$ & Vertebrates & IC\&EC \\
\hline
\end{tabular}

IC = Intracellular; HGA = : human granulocytic anaplasmosis ; HGE = human granulocytic erlichiosis; * = Relevant co-infections are highlighted in bold. 
Table 2. Positive Serology and Positive LTT for Co-infections (\%) in Patients with Chronic Lyme Disease, N = 108

\begin{tabular}{|l|l|l|l|}
\hline \multicolumn{1}{|c|}{ Pathogen } & \multicolumn{1}{c|}{ N } & Positive Serology (\%) & Positive LTT (\%) \\
\hline \hline Mycoplasma pneumoniae & 36 & 36 & $\mathrm{Nd}$ \\
\hline Chlamydophila pneumoniae & 66 & 62 & 66 \\
\hline Chlamydia trachomatis & 100 & 5 & 100 \\
\hline Yersinia enterocolitica & 58 & 58 & 50 \\
\hline Bartonella henselae & 78 & 78 & $\mathrm{Nd}$ \\
\hline
\end{tabular}

LTT = lymphocytic transformation test; Nd = not done, LTT=LPT (lymphocyte proliferation test).

Table 3. Main Disease Manifestations of Bartonellosis

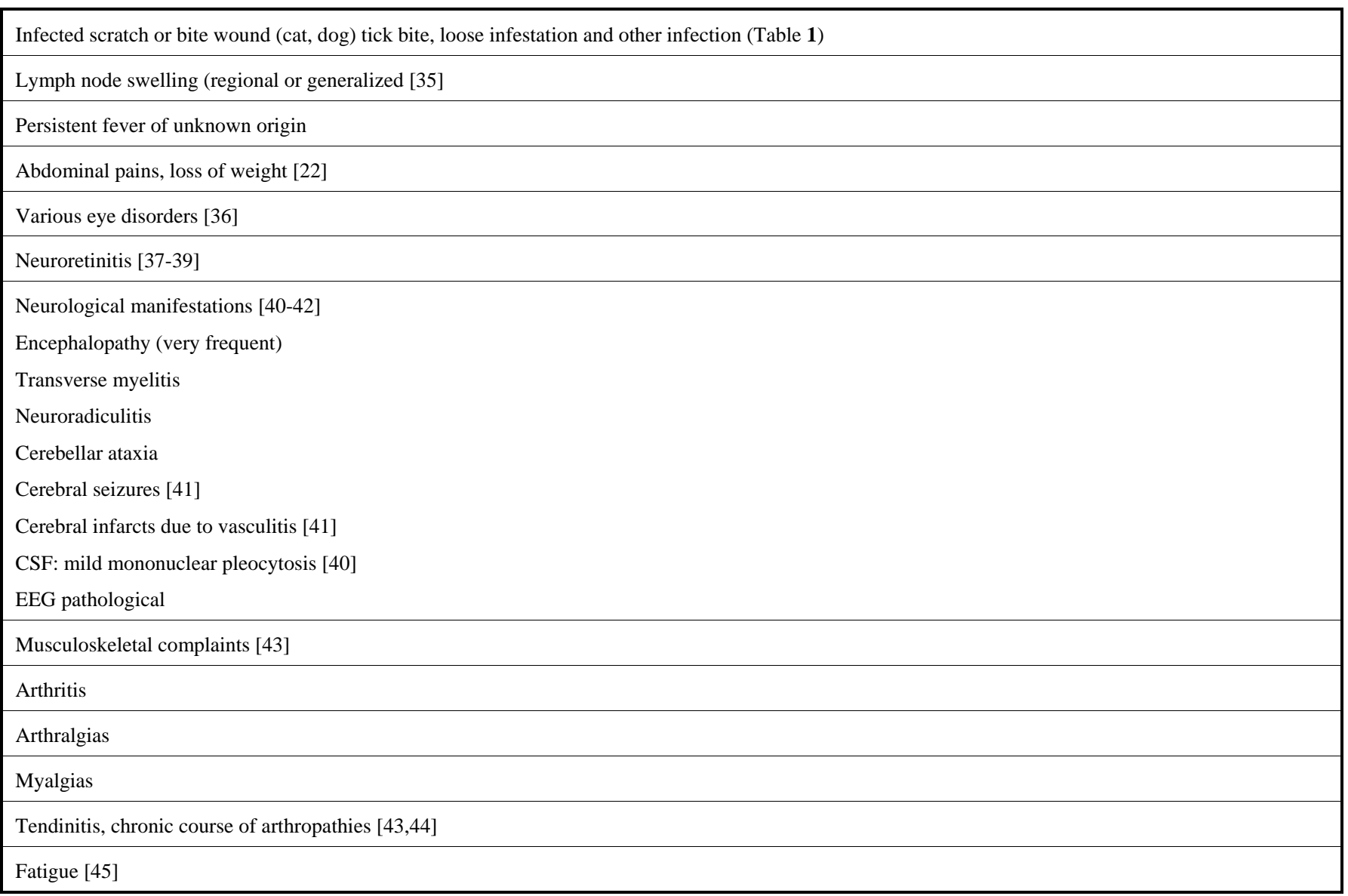

diminished in all chronic infectious diseases, but the phenomenon is observed relatively frequently in chronic LD.

In contrast to the USA, human granulocytic anaplasmosis (HGA) or human granulocytic ehrlichiosis (HGE) and babesiosis are of little importance as co-infections in Europe.

\section{BARTONELLOSIS}

Bartonellosis can be expected to have substantial significance as a Lyme disease co-infection. With regard to the health policy aspect, Lyme disease is more important because of its frequency. However, in this context it should be noted that bartonellosis has not been nearly as intensively investigated as Lyme disease. With the increasing develop- ment of laboratory tests, one may expect that the currently underestimated prevalence of bartonellosis will be more correctly registered in the future. The importance of this disease will also be determined on the basis of its frequency. My own observations also show that the serology for Bartonella is frequently positive in patients with chronic Lyme disease.

All facets of the transmission mode of bartonellosis have not yet been clarified. The most important data reported in the scientific literature are summarized in Table $\mathbf{1 .}$

Bartonellosis (caused by Bartonella henselae and Bartonella bacilliformis) can be associated with a high variety of symptoms (Table 3 ). The bacterial inflammatory skin infection (scratch or bite location) is in no way obligatory, i.e. 
Table 4. Symptomatology of Bartonellosis

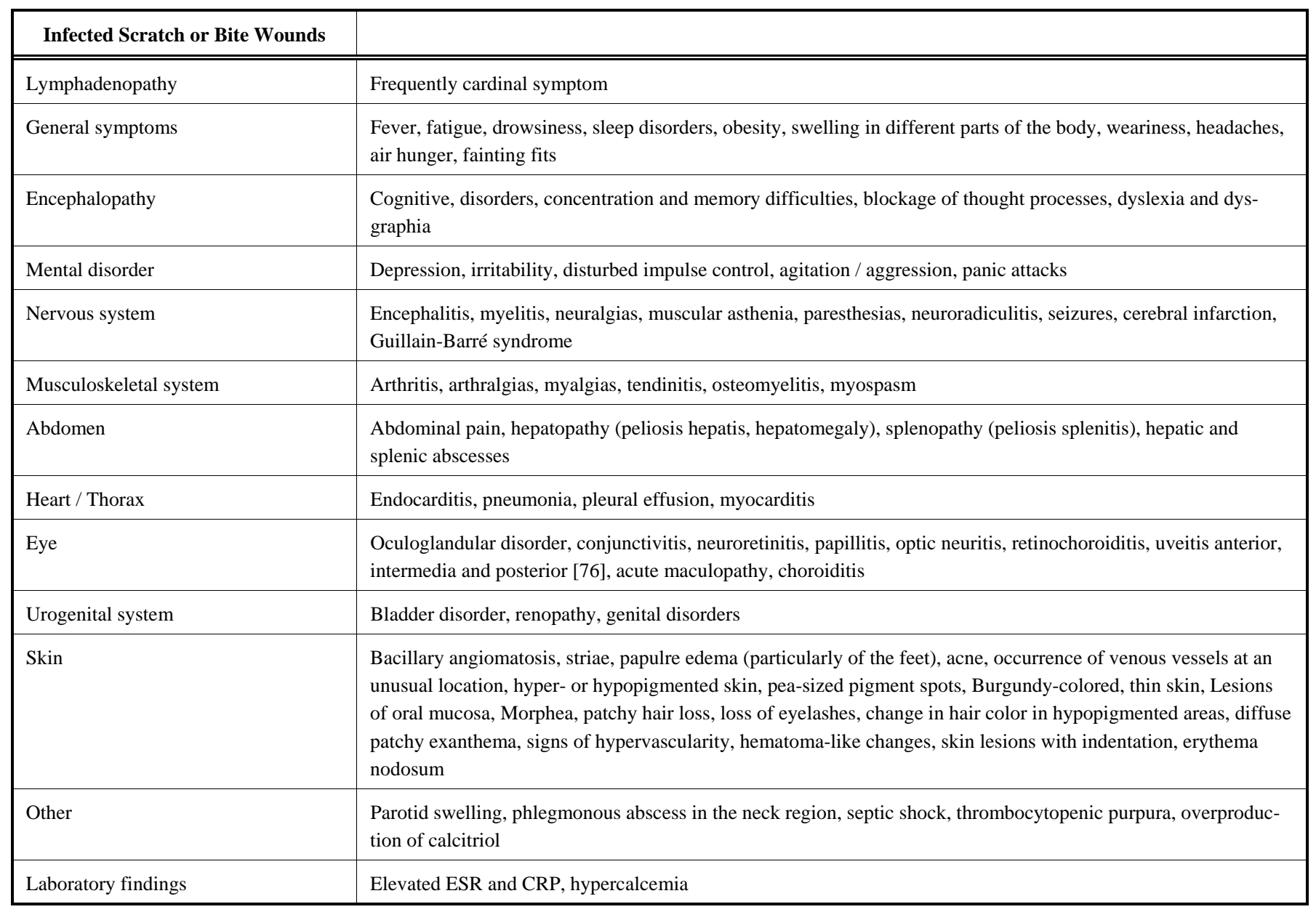

bartonellosis can also occur without the typical cat scratch disease, which is characterized by infected skin lesion and lymph node swelling. The main manifestations of the disease comprise in addition to infected skin lesion and swollen lymph nodes various multi-organ disorders (e.g. liver, spleen, nervous system, eye) [18-19], $c f$. Table 3.

Until 1993 only B. bacilliformis was known. The different Bartonella subspecies were first described and their pathological significance recognized in 1993 [22].

There are numerous overlaps with Lyme disease in the clinical manifestations of bartonellosis [46]. The laboratory diagnosis for bartonellosis is based on the analysis of blood smear, on the serology, on pathogen detection using culture methods and PCR and on the histopathological investigations. In early stage the laboratory findings show elevated erythrocyte sedimentation rate (ESR) and C-reactive protein (CRP) level as well as hypercalcemia.

In cases of infection with Bartonella, the blood smear initially shows pathogens on the outer membranes of erythrocytes, and in the further course of the disease the pathogens are increasingly localized intracellularly. In the process, the light colored center of erythrocytes is lost (Fig. 1).

There is no information on the value of serology in the literature. In particular, the question as to whether seronegativity rules out the disease has not been clarified. On the other hand, as it is the case for many other infectious diseases, a positive serological finding merely proves that an infection took place, but does not indicate active disease.

Detecting Bartonella in culture is difficult, and the sensitivity is very low, therefore this method of investigation is not part of the routine diagnostics. Detection of pathogens using PCR in biopsies appears to be promising $[47,48]$, but PCR analysis must follow the biopsy nearly immediately [49].

Chronic course of bartonellosis has been described in numerous studies, including in larger population studies [5054]. The long duration of the disease frequently for several years, and the similar disease manifestations, makes it difficult to distinguish bartonellosis from chronic Lyme disease. Thus, bartonellosis is of great importance in the differential diagnosis of Lyme disease. In this context, attention should be paid to the fact that Bartonella henselae has been found in ticks and that transmission of Bartonella henselae by ticks to human has been documented by detecting the pathogen in the CSF [55]. Additionally, the prevalence of Bartonella henselae in ticks is apparently high; scientific studies determined a prevalence of $40 \%$ [56]. According to my own surveys, $78 \%$ of the patients with chronic Lyme disease proved to be seropositive for Bartonella henselae (Table 2).

Bartonellosis is accompanied by a stimulation of blood vessel formation, inducing vascularized tumors or granu- 


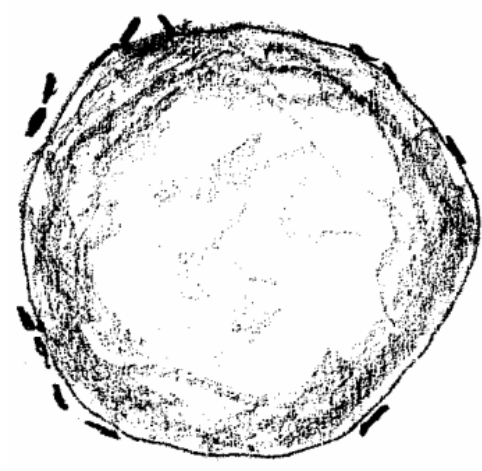

A.

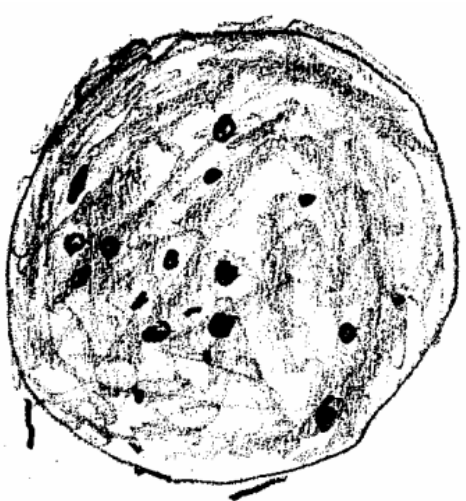

B.

Fig. (1). Erythrocytes infected with Bartonella henselae. A. At an early stage, the microorganism lies outside of the erythrocytes; B. With increasing duration of infection, the bacterium is primarily intracellular and erythrocytes loose their light-colored center.

lomas in various regions of the skin (bacillary angiomatosis), in the liver (peliosis hepatis) or in the spleen (peliosis splenitis) [57-59]. These vascular tumors or granulomas exhibit a pathological sprouting of capillaries with hyperplasic and hyperproliferative endothelial cells [60]. In addition to angiomatosis, Bartonellosis also results in various other skin manifestations associated with increased vessel formation [23], therefore the determination of vascular endothelial growth factor (VEGF) in blood could be of diagnostic importance [23].

In all pathogenic Bartonellae (Bartonella quintana, Bartonella henselae, Bartonella bacilliformis) this effect on endothelial cells and on the induction of angiogenesis has been demonstrated. The vascular proliferation was primarily traced back to three factors [61-67], namely to elevated endothelial cell proliferation, to inhibition of endothelial cell apoptosis and to increased secretion of vasculo-proliferative cytokines. All these studies support the significant role of VEGF in Bartonella-induced endothelial cell proliferation [67].

Bartonellae are localized in erythrocytes and cause the deformation of erythrocyte membrane [68, 69]. The visualization of bartonellae in erythrocytes is used as a diagnostic tool, particularly with regard to the extent of infection [69]. However, irrefutable literature on erythrocyte infestation in chronic bartonelloses does not exist. The diagnostic value of a new method detecting the pathogen by means of cilia in blood smears cannot be assessed yet. The formation of intra-

Table 5. Antibiotic Treatment of Bartonellosis

\begin{tabular}{|c|c|c|}
\hline Antibiotic & Dose / Day & References \\
\hline Telithromycin & $800 \mathrm{mg}$ & [89] \\
\hline Rifampicin & $600 \mathrm{mg}$ & {$[84,89,90,91,93,95,96,98$} \\
\hline Ciprofloxacin & $1000 \mathrm{mg}$ & {$[84,89,92-94,98]$} \\
\hline Doxycycline & $400 \mathrm{mg}$ & {$[86,89,90,91,94-96]$} \\
\hline Minocycline & $200-300 \mathrm{mg}$ & [93] \\
\hline $\begin{array}{l}\text { (Other recommendations: erythromycin, roxithromycin, penicillin G, sparfloxacin, chlo- } \\
\text { ramphenicol, streptomycin, gentamycin, Augmentin, ticarcillin, cefotaxime, ceftriaxone, } \\
\text { meropenem, trimethoprim and sulfamethoxazole. The information in the various publica- } \\
\text { tions is very contradictory. This is particularly true for gentamycin. Beta-lactam antibiotics } \\
\text { do not act intracellularly and are therefore not suitable for the treatment of bartonellosis } \\
\text { (author's comment) [84,85,87,88,90,91,93,94,97,98-102]. There are substantial discrepan- } \\
\text { cies between in vitro findings and in vivo efficacy. }\end{array}$ & & \\
\hline $\begin{array}{l}\text { Duration of treatment (no reliable data basis) } \\
\text { Acute early phase }\end{array}$ & 2 weeks & \\
\hline Chronic course & 2 - 3 months & \\
\hline
\end{tabular}


cellular blebs subsequent to the penetration of the organism into endothelial cells has also been showed for Bartonella quintana, i.e. a similar process to that observed on Borrelia burgdorferi in Lyme disease. Borrelia burgdorferi also has a high affinity for endothelial cells, and the development of blebs, particularly in chronic disorders, has been described. In connection with Lyme disease, the intracellular presence of the pathogen and the formation of biologically less active and more resistant forms (cysts, blebs) have been discussed as the cause of the failure of antibiotic treatment. Corresponding Additional parallels have been also found between Lyme disease and bartonellosis [cf. 70-75].

Two additional forms of bartonellosis merit to be noticed namely, the Oroya fever or Verruga peruana and the trench fever. Oroya fever and its recognition as an infectious disease date back to Carrion, who verified that the disease is infectious in a fatal self-test at the end of the 19th century. Trench fever was discovered at the beginning of the 20th century. Its transmission occurs via lice [77-79]. In 2002 the pathogen was detected for the first time in erythrocytes; as a result the transmission by lice became plausible [21]. Oroya fever and Verruga peruana are both Bartonella bacilliformis infections transmitted by sand flies. The disease occurs in the Andes. The acute form affects tourists who are immunologically naive with respect to Bartonella bacilliformis. Without treatment the mortality rate is $40 \%$. To date, the factor, which influences the severe disease course is unknown.

Adequate studies are missing for the treatment of bartonellosis. There is no single treatment approved by the US Food and Drug Administration (FDA), the Center for Disease Control (CDC) or the Infectious Diseases Society of America (IDSA) [23]. This applies particularly for the chronic courses of the disease [80]. The use of the following antibiotics are recommended (Table 5): azithormycin [81,82], rifampicin, ciprofloxacin, trimethoprim combined with sulfamethoxazole, gentamycin [83,84], gentamycin i.v. [85], and doxycycline combined with gentamycin [86, 87]. This treatment is based, in part, on expert recommendations [88]. Further Other references are listed in Table $\mathbf{5}$.

The discrepancy between the in vitro findings and the in vivo results is set out in various publications [93,97,99, 102,103].

Since Bartonella henselae is primarily localized intracellularly in vivo, only antibiotics that act intracellularly are used; they are listed in Table 5.
Because instances of non-response and recidivism are not seldom in cases of chronic bartonellosis, long-term antibiotic treatment is recommended [89,99,102-104].

The efficacy of aminoglycosides (particularly gentamycin) is extremely controversially assessed. Publications with a positive assessment $[92,94,95,99,102]$ are in opposition to other contributions, which assess aminoglycosides as ineffective or insufficiently effective $[90,91,93]$.

\section{Chlamydophila pneumoniae}

Chlamydophila pneumoniae is important in the differential diagnosis of Lyme disease because it can cause nervous system disorders, myocarditis and reactive arthritis.

Chlamydias have special microbiological characteristics. The size of the pathogen is very small compared to other bacteria. Reproduction occurs within host cells and the pathogen is dependent on host cell ATP as it is not capable to produce its own. The pathogen exhibits two phenotypes, the elementary bodies and the reticulate bodies. The elementary bodies can exist extracellularly and represent the infectious form. Reproduction of the elementary bodies is only possible inside of host cells. Host cells phagocytize the elementary bodies, which intracellularly transform into reticulate bodies and undergo division. The elementary bodies are thus infectious, and the reticulate bodies reproductive. Some reticulate bodies can change back into elementary bodies, which are released subsequently to host cell lysis. The released elementary bodies infest then further host cells. Consequently, precondition for an adequate treatment is both the intra- and extracellular efficacy of the antibiotic. This is the case for tetracyclines and macrolides (Table 6).

The primary disease manifestation of Chlamydophila pneumoniae is pneumonia. The incidence is $1 \%$ and predominantly affects people older than 65 years $[105,106]$. The pneumonia is frequently accompanied by infections of the upper respiratory tract (pharyngitis, laryngitis, sinusitis). An initially slight disease expression, extrapulmonary manifestations [107] and a normal leukocyte count indicate atypical pneumonia, suggestive of Chlamydophila pneumoniae infection. Extrapulmonary manifestations include nervous system disorders including Guillain-Baré syndrome and meningoencephalitis, as well as reactive arthritis and myocarditis, which are significant with regard to the differential diagnosis

Table 6. Antibiotic Treatment of Chlamydophila pneumoniae

\begin{tabular}{|c|c|}
\hline Antibiotic & Dose / Day \\
\hline \hline Azithormycin & $500 \mathrm{mg}$ \\
\hline Clarithromycin & $1000 \mathrm{mg}$ \\
\hline Telithromycin & $800 \mathrm{mg}$ \\
\hline Doxycycline & $400 \mathrm{mg}$ \\
\hline Gemifloxacin & $320 \mathrm{mg}$ \\
\hline Rifampicin (in combination with doxycycline or azithormycin) & $600 \mathrm{mg}$ \\
\hline Treatment duration for chronic course (no reliable data basis) & 2 - 3 months, if necessary 6 months for so-called reactive arthritis [108] \\
\hline
\end{tabular}


of Lyme disease or Lyme neuroborreliosis.

The extrapulmonary manifestations frequently extend across a long period of time, i.e. through months or years. This also applies to the so-called reactive arthritis, whose differentiation from Lyme disease arthritis is sometimes difficult. Attention should also be paid to Guillain-Barré syndrome, which can last for months, and with a similar manifestation to that observed in Lyme disease. The association with a myocarditis is also similar, whereas meningoencephalitis occurs in the acute phase, almost simultaneously with pneumonia.

The chronic course of Chlamydophila pneumoniae infections is documented by several studies [108-114]. A relationship to Chlamydophila pneumoniae was also described in Alzheimer's disease [115]. This finding is of importance with regard to chronic Lyme neuroborreliosis, for which the same associations have been demonstrated [116-119].

The laboratory diagnosis for Chlamydophila pneumoniae includes serology, the lymphocyte transformation test (LTT), and the detection of the microorganism using PCR.

The serological tests have severe inherent limitations. There is a considerable discrepancy between the serological findings, on the one hand, and pathogen detection using PCR, on the other hand $[120,121]$. A single test for IgG has a low sensitivity [122], whereas the sensitivity is quite good in cases of a definite increase in IgG between the acute phase and the further course of the disease. The diagnostic value of LTT for Chlamydophila pneumonia has not yet been validated in the literature. The chronic disease course obviously represents a chronic persistent infection. Chlamydophila pneumoniae could be detected both in the synovial fluid and in the liquor using PCR [108-110,113,114].

Antibiotic treatment of Chlamydophila pneumoniae is given in Table $\mathbf{6}$. The drug of choice is doxycycline; macrolides also exhibit good efficacy, particularly azithormycin; quinolones have a low efficacy [123], however, gemifloxacin has proven to be very effective [124].

\section{Chlamydia trachomatis}

The variable microbiological appearance of Chlamydia trachomatis is similar to that of Chlamyophila pneumoniae, described above. That the infectious form of Chlamydia trachomatis is present both intra- and extracellularly is decisive with regard to the efficient antibiotic treatment of the disease.

Chlamydia trachomatis is sexually transmitted and causes urogenital infection. The differential diagnostic problem with respect to Lyme disease results primarily from chronic arthritis, which is caused by persistent infection in both diseases. In Chlamydia trachomatis infection, this chronic arthritis is assigned to the so-called reactive arthritis even though that in some studies the pathogen was detected in the synovial fluid, which indicates persistent infectious arthritis $[125,126]$. Arthritis occurs in $1 \%$ of the cases with Chlamydia trachomatis urethritis. Reiter's triad (arthritis, uveitis, urethritis) occurs in only $0.3 \%$ of the affected patients.

The disease can be easily detected by laboratory diagnostic tests in cases of existing urogenital infection. Nucleic acid amplification techniques (NAATs) for urethral smear or urine are available, which are also reliable for asymptomatic patients [127-129]. PCR has also a high sensitivity and specificity [130]. The diagnostic value of the serology and LTT has not yet been validated. Moreover, whether a chronic infection with Chlamydia trachomatis can be accompanied by seronegativity, as in Lyme disease, has not been clarified. Seropositivity can provide evidence of a previous infection, but does not allow conclusion with regard to a persistent infection with Chlamydia trachomatis. Theoretically, persistent or reproducible pathological LTT indicates prolonged infection, but scientific data for the diagnostic value of LTT are not yet available.

Treatment of Chlamydia trachomatis infection is similar to that of Clamydophila pneumoniae (Table 6). Duration of treatment is 3 months [108]. In case of arthritic Sulfasalazine [131] and treatment by TNF antibodies [132] were also proposed.

\section{Yersinia enterocolitica Infection (Yersiniosis)}

The infectious data and symptomatology of yersiniosis are compiled in Tables $\mathbf{1}$ and 7, respectively. Yersinia enterocolitica was already recognized as pathogen as early as the beginning of the 20th century. However, the true signifi-

Table 7. Yersiniosis (Y. enterocolitica) Symptomatology

\begin{tabular}{|c|l|}
\hline Stages & \multicolumn{1}{c|}{ Symptoms } \\
\hline \hline Early stage & $\begin{array}{l}\text { Gradual development of gastroenteritis, pharyngitis, complications due to inflammation of the intestinal wall, mesenteric lymphade- } \\
\text { nopathy. } \\
\text { Excretory for months after abatement of gastroenteritis }\end{array}$ \\
\hline Late stage & $\begin{array}{l}\text { Articular manifestations: Reactive arthritis in hip, knee, upper ankle, sacroiliac joints, arthralgias, ankylosing spondylitis, rheumatoid } \\
\text { arthritis, sacroilitis } \\
\text { Erythema nodosum, iridocyclitis, conjunctivitis, gastrointestinal complaints, abdominal pain, diarrhea, ulcerative colitis, nephritis, } \\
\text { insulin-dependent diabetes mellitus, hepatitis (ANA positive, rheumatoid factor positive), myocarditis (rare), central and peripheral } \\
\text { nervous system manifestations, multisystem disease } \\
\text { Disease progression in stages with intervals of fewer complaints } \\
\text { Correlation with thyroiditis } \\
\text { Positive LTT } \\
\text { Oscillating serological findings (correlation with disease expression) }\end{array}$ \\
\hline
\end{tabular}


cance of the pathogen, in particular, under epidemiological aspects was first described in 1995 [133]. Acute illness due to Yersinia enterocolitica is subject to registration (according to German law). The pathogen penetrates into the intestinal wall and the mesenteric lymph nodes. Surface proteins and plasmid-bound virulence factors suppress immune system reactions of the host [134-137].

The early stage of yersiniosis is essentially characterized by gradually developing gastroenteritis and pharyngitis and mesenteric lymphadenitis.

In contrast to other bacterial gastroenteritis, Yersinia enterocolitic gastroenteritis develops gradually and often becomes stressfull or perceivable only after a week [138140]. Frequently, the infection is associated with pharyngitis because the pathogens remain in the lymphatic tissue of the tonsils and the pharyngeal wall, where they can also be detected by means of smear test. The concurrent occurrence of gastroenteritis with pharyngitis is typical for a yersiniosis [141].

The mean disease duration is approximately two to three weeks, but distinctly longer disease course have been described. The acute illness can be associated with numerous gastrointestinal complications, primarily as a consequence of a severe bacterial inflammation of the intestinal wall [142144]. In addition, the disease can also affect many nongastrointestinal organs [142,143,145-148]. The patients frequently remain excretory for months, even when the gastroenteritis has long since abated [139].

Yersiniosis can result in so-called reactive arthritis and is thus an important infectious disease in the differential diagnosis of Lyme disease. Since the disease can also sporadically occur [139] and frequently remains unrecognized, the anamnestic search for the typical manifestations of yersiniosis particularly symptoms of the early phase is of considerable importance.

Differentiation between Lyme disease and yersiniosis is made even more difficult by the fact that both infections can cause multisystem disease. The study by Saebo und Lassen [149], which describe the various disease manifestations in a retrospective study of 458 patients, is of particular importance for the depiction of chronic yersiniosis: chronic persis- tent arthralgias, ankylosing spondylitis, rheumatoid arthritis, iridocyclitis, chronic abdominal pains, chronic diarrhea, ulcerative colitis, nervous disorders, nephritis, thyroid disorders, insulin-dependent diabetes mellitus, chronic hepatitis, (multisystem diseases) and a substantial reduction of the overall life expectancy. Many of the different relationships were reported in further publications by these authors [150155]. Studies suggesting a possible direct relationship between Yersinia and inflammatory intestinal disorders [155] close the pathophysiological circle between Yersinia, inflammatory intestinal disorders and enteropathic arthritides. Despite this, it should be noted that the relationship between Yersinia infection and the above-mentioned numerous disease manifestations (except for arthritis) have been inadequately analyzed. This may be due to the fact that the significance of "yersiniosis" as a disease has only been recently recognized.

In the differential diagnosis of yersiniosis with respect to Lyme disease and other co-infections, the importance is primarily based on the manifestation of a so-called reactive arthritis. This arthritis can last for months, and exhibit recurrent and symptom-free intervals in the disease course. The so-called reactive arthritis in yersiniosis can occur alone, but occasionally also in connection with conjunctivitis and urethritis, previously termed Reiter's syndrome [156]. As in Chlamydia infections and possibly in bartonellosis, the arthritis is probably the consequence of chronic persistent infection $[157,158]$.

The so-called reactive arthritis primarily affects the hip, knee and upper ankle joints as well as the sacroiliac joints; occasionally there are additionally chronic pains in the lumbosacral region [159].

In the differential diagnosis of Lyme disease, it is of particular interest that in some studies Yersinia enterocolitica was detected in articular effusions in case of the so-called reactive arthritis $[157,158]$. Sometimes these arthritides last for many years. In addition, there is a relationship between yersiniosis and thyroiditis. All these (chronic arthritides, multisystem disorders, disease course lasting for years, correlation with regard to thyroiditis) can also be observed in Lyme disease.

The laboratory diagnostics of Yersinia enterocolitica infection is based on the seriological findings, on the LTT

Table 8. Antibiotic Treatment of Yersinia enterocolitica Infection

\begin{tabular}{|l|l|}
\hline \multicolumn{1}{|c|}{ Antibiotic } & \multicolumn{1}{c|}{ Dose / Day } \\
\hline \hline Ceftriaxone + Gentamycin & $2 \mathrm{~g}+240 \mathrm{mg}$ \\
\hline Ciprofloxacin & $1000 \mathrm{mg}$ \\
\hline Trimethoprim and sulfamethoxazole & $875 \mathrm{and} 125 \mathrm{mg}, \mathrm{x} 2 \mathrm{daily}$ \\
\hline Gentamycin & $240 \mathrm{mg}$ \\
Doxycycline & $400 \mathrm{mg}$ \\
\hline Piperacillin & $8 \mathrm{~g}$ \\
Entapeneum & $1 \mathrm{~g}$ \\
\hline Rifampicin (in combination with doxycycline or azithormycin) & $600 \mathrm{mg}$ \\
\hline Treatment duration for chronic course (no reliable data basis) & 2 - 3 months, if necessary 6 months for so-called reactive arthritis [108] \\
\hline
\end{tabular}


findings and on pathogen detection by PCR and culture.

As in Lyme disease, there is often seropositivity in asymptomatic patients. Information on a possible seronegativity in chronic yersiniosis is not available. In the disease course the serological findings can correlate with disease expression [159]. It is not rare that a highly significant pathological Yersinia LTT is found in patients whose complaints are primarily consistent with chronic Lyme disease. Positive yersinia LTT could be an indication of chronic persistent infection especially when reproducible.

Pathogen detection is possible, particularly in articular effusion and in lymphatic tissue of the intestine and in early stages of the disease by throat swab. Data on the sensitivity of pathogen detection using PCR or culture methods does not exist in the relevant literature. In Yersinia-PCR-positive patients, the serology was positive in $70 \%$ and LTT in 50\% of the cases analyzed [160]. In the initial detection of Yersinia enterocolitica using culture methods, IgA and IgG bands were found in immunoblot assay in patients experiencing a chronic course of the disease. The continuous detection of IgA antibodies was obviously an expression of persistent infection; in this context the pathogens were detected in the intestinal mucosa and in lymphatic tissue. Hence, this was a definitely chronic, persistent Yersinia enterocolitica infection [161]. The antibiotic treatment of Yersinia enterocolitica infection is presented in Table $\mathbf{8}$.

Yersiniosis frequently abates within a few weeks so that an antibiotic treatment is not generally recommended. This also applies with regard to excretors. Antibiotics are used only in cases with severe disease courses, in particular with sepsis. Y. enterocolitica produces beta-lactamases with the consequence that penicillin, ampicillin and cephalosporins of the first generation are ineffective [162,163]. Resistance to macrolides is also frequent. It is disputed whether early antibiotic treatment (i.e. for gastroenteritis) prevents reactive arthritis [164].

The differential diagnosis of chronic yersiniosis vs chronic Lyme disease, is thus extremely difficult because of the overlap of various clinical symptoms. In cases where both infections are present in their chronic form, a differentiation is often impossible.

\section{Mycoplasma pneumoniae Infection}

Table 9. Mycoplasma pneumoniae Infection: Symptoms

\begin{tabular}{|l|l|}
\hline $\begin{array}{l}\text { Pulmonary and related } \\
\text { (older people in nursing and old people's homes are frequently affected) } \\
\text { Incubation period 3 weeks }\end{array}$ & $\begin{array}{l}\text { Atypical pneumonia (3\% - 10\% of cases.) } \\
\text { bronchitis, pharyngitis, rhinitis, earaches, sinusitis }\end{array}$ \\
\hline Extrapulmonary & $\begin{array}{l}\text { Maculopapular exanthema,vesicular dermatitis } \\
\text { CNS disorders (are rare): encephalitis, meningitis, myelitis, cranial neuropa- } \\
\text { thy, cerebellar ataxia }\end{array}$ \\
\hline Gastrointestinal & Hepatitis, pancreatitis \\
\hline Rheumatic & Arthritis: arthralgias, myalgias, polyarthritis \\
\hline Cardiac & Cardiac arrhythmias, atrioventricular block, myocarditis \\
\hline Glomerulonephritis & \\
\hline Uveitis & \\
\hline
\end{tabular}

The differential diagnosis between Lyme disease und Mycoplasma pneumoniae infection or the recognition of the co-infection by Mycoplasma pneumoniae is problematical because both diseases exhibit similar manifestations; this applies to the extrapulmonary manifestations of Mycoplasma pneumoniae infection: disorders of the CNS, musculoskeletal system, heart, kidney and eye.

Data related to Mycoplasma pneumonia infection are given in Table $\mathbf{1}$ and $\mathbf{9}$. In the foreground is the atypical pneumonia, frequently linked to symptoms of the upper with respect to the frequency of extrapulmonary manifestations.

Mycoplasma pneumoniae is considered to be the most important pathogen of atypical pneumonia. However, pneumonia only occurs in approximately $3 \%-10 \%$ of the cases in Mycoplasma pneumoniae infection [165]. In most cases, the infection results in a banal bronchitis [165], pharyngitis, rhinitis, earaches, and sinusitis [163].

All the extrapulmonary disease manifestations listed in Table 9 are seldom [166-174]. In patients with arthritis, Mycoplasma pneumoniae was detected in the synovial fluid by PCR [171], which is an indication of a direct relationship to infection.

The detection of pathogen in articular effusion and many extrapulmonary manifestations of the disease document the chronic course of the disease in cases with Mycoplasma pneumoniae infection. However, precise data on the chronic course of the disease are not available in the literature. In particular, whether a chronic infection, especially with extrapulmonary disease manifestation, can persist with seronegativity is unclear. Seropositivity documents infection, but cannot serve as a proof for chronic persistent Mycoplasma pneumoniae infection.

The literature on the relationship between Mycoplasma pneumoniae infection and neurological disease manifestations is extensive. The publications primarily refer to neurological complications in pneumonia, i.e. the early phase of Mycoplasma pneumoniae infection. Neurological manifestations involve both the early phase, i.e. the point in time of existing pneumonia due to Mycoplasma pneumoniae, and later disease stages. Changes in the region of the brain stem respiratory tract. There are no data available in the literature 
[175, 176], myelitis [177-187], Guillain-Barré syndrome [188-193], encephalitis [185,187,194-200], meningitis [194], polyradiculopathy [178], peripheral facial paresis [201, 202], optical neuritis and hemorrhagic leukoencephalitis [190], peripheral polyneuropathy[194], cranial nerve neuritis [192], radiculitis [192] have been described.

The frequency of neurological symptoms in connection with Mycoplasma pneumoniae varies between 1\% [203], 1\% [204], and 5\% [205]. The pathogen has been repeatedly detected by means of culture methods or PCR [182,193,194].

The detection of pathogen in the serum and liquor is considered to be proof that the neurological manifestations are mediated by direct infection and not by immunological responses [193]. However, the connection between Mycoplasma pneumoniae and neurological manifestations is not undisputed [203, 206].

Other extrapulmonary manifestations mentioned in the literature include hepatitis, hemolytic anemia, SchönleinHenoch purpura, disorders of the muscular-skeletal system, of the skin and other organs [179], macula edema[194], bilateral uveitis [207], nephritis [208], arthritis, hepatitis and pericarditis [208].

The laboratory diagnostics for Mycoplasma pneumoniae include the serology, which as in most infectious diseases becomes positive after several weeks. Seroconversion is therefore significant for the chronic disease course. Seropositivity substantiates the infection, but not the disease. Whether a chronic infection can also exist in seronegative cases has not yet been scientifically clarified. The LTT for Mycoplasma pneumoniae has not yet been validated.

Detection of the pathogen, e.g. in articular effusion by PCR and culture is possible but difficult and has a low sensitivity. Consequently it is not part of the routine diagnostic procedures.

In the antibiotic treatment of Mycoplasma pneumoniae the drugs of choice are azithormycin $500 \mathrm{mg} /$ day [209], levofloxacin $500 \mathrm{mg} /$ day [210] and doxycycline $400 \mathrm{mg} /$ day.

\section{Human Granulocytic Anaplasmosis (HGA)}

The pathological importance of human monocytic ehrlichiosis (HME) and human granulocytic anaplasmosis (HGA), which is also called human granulocytic ehrlichiosis (HGE), was discovered in 1986 and 1994, respectively [211, 212]. The two infectious diseases resemble each other clinically and with regard to the laboratory findings. The pathogens develop in monocytes (HME) or in granulocytic leukocytes (HGA). Thus, their localization is exclusively intracellular.

The pathogens are transmitted by infected ticks, primarily via Ixodes scapularis in the United States and via Ixodes ricinus in Europe. The reservoirs are the white-footed mouse for HGA and the red deer and human beings for HME (Table 1). Other modes of transmission are also discussed, including mother-child transmission, blood transfusions, direct contact with infected animals and transmission form person to person [213-219].

In connection with ehrlichiosis or anaplasmosis, two pathogens are to be noted, respectively, namely Ehrlichia chaffeensis [220] and Anaplasma phagocytophilum [221]. E. chaffeensis infects monocytes and Anaplasma Phagocytophila granulocytes.

Ehrlichia chaffeensis is the pathogen of human monocytic ehrlichiosis (HME), a rare infectious disease, which occurs primarily in the USA and in some regions of South America, but practically nowhere else on earth. Ehrlichia phagocytophila is the pathogen of human granulocytic anaplasmosis (HGA), another extremely rare disease in the USA with an annual incidence of approximately $10 / 1$ million inhabitants [222]. HGA, is an important co-infection of Lyme disease in the USA, but not in Europe.

The pathogen can be simultaneously transmitted with Borrelia burgdorferi with the consequence of a double infection. HGA exhibits many symptoms, which also occur in Lyme disease.

Scientific reports on illnesses due to HGA in Europe are rarities [223]. However, studies in Northern Italy showed that $24 \%$ of the ticks (I. ricinus) were infected by Ehrlichia chaffeensis or Anaplasma phagocytophilum. Similar findings have been substantiated in the Netherlands and in Poland, whereas in Germany the frequency is approximately 2\% [224-229]. In the East Coast of the United States it is much higher and reaches approximately 30\% - 40\% [230,231].

In Europe, in patients with Lyme disease the seroprevalence for Anaplasma phagocytophilum is approximately $10 \%$ [232-234]. Similar findings were also obtained in the USA [235]. Since seroprevalence merely expresses the frequency of the infection, but not an ungoing active infection of HGA, no reliable statements about the prevalence of the disease can be made. According to the laws of probability, a concurrent HGA infection in patients with Lyme disease might amount to a few percent at most. There are no data available in the literature on chronic HGA courses. However, subacute and chronic courses are discussed [236, 237].

The incubation period, i.e. the time between tick bite and emergence of acute illness, is approximately one week [238]. In the acute phase clusters of bacteria are located intercellularly (morale) [239].

The clinical symptoms comprise fever, influenza-like symptoms, headache, joint and muscle pains, coughing, CNS disorders, which include meningitis. Such changes occur frequently and are - particularly in cases involving a febrile clinical picture with the above-mentioned symptoms - an indication for HGA. Indications of HGA are the pathological laboratory findings of leukopenia, thrombocytopenia, and elevated transaminases. The pathogen is localized intracellularly. Anemia and elevated creatinine can rarely occur.

The diagnosis of HGA (also as co-infection) is based on the anamnesis, on the clinical symptoms and laboratory findings, including the serological findings [240-243] and the detection of pathogens. The specific antibodies appear two to three weeks after disease onset and persist following the decline of the disease. Therefore, a positive serology does not confirm ongoing infection of HGA. The pathogen is detected in blood smear, which is not often successful; [244247], or by PCR from whole blood. The detection by PCR was successful in $20 \%-80 \%$ of the cases analyzed, with a sensitivity of $60 \%-80 \%$ [248-251]. 
Doxycycline is the recommended therapy, also for children. Precise literature with regard to an adequate treatment is not available.

\section{BABESIOSIS}

Babesiosis, similarly to HGA, is an important coinfection in the USA, but not in Europe. Babesiae are protozoa and result in lysis subsequent to invasion of erythrocytes. Two species of Babesia are pathogenetically significant, namely Babesia microti and Babesia divergens [29,30]. Babesia microti is the predominant pathogen in the USA and Babesia divergens in Europe [cf. 252]. The transmission of the pathogen occurs primarily via ticks, namely Ixodes ricinus in Europe and Ixodes scapularis in the USA [29,30]. Babesia microti has been found as a co-infection in Lyme disease [253-255]. Other modes of transmission are blood transfusions [31] and perinatal infection [32,33]. The reservoir is the cattle and probably other vertebrates (Table $\mathbf{1}$ ).

Since 1956 a total of only 30 cases has been reported in Europe. The majority of these patients were splenectomized. The prevalence of Babesia microti and Babesia divergens in ticks is $10 \%-20 \%$ in Europe [256-258], and somewhat higher in the U.S.A. [259]. The seroprevalence with regard to Babesia microti and Babesia divergens is $0 \%$ in European patients with Lyme disease [260,261] and thus is in stark contrast with the frequency of the pathogen in ticks.

The situation in the USA is different, where the seroprevalence is approximately $10 \%-20 \%$ [262-265] where the disease was reported to occur more frequently, in some cases with severe disease courses [266-269]. This difference can obviously be only explained by the fact that Babesia microti, the predominant pathogen in the USA, has a much higher virulence than Babesia divergens. Thus, Babesiosis dos not play a major role in Europe unless the patient contracted the disease in a foreign country, e.g. in the USA.

The clinical picture presents as a febrile, influenza-like medical condition with chills, fever, arthralgias, myalgias, and gastrointestinal symptoms. Severe disease courses only occur in non-immunocompetent patients. The diagnosis is based in addition to the anamnesis and the clinical picture, on the serological findings $[270,271]$ and on the detection of the organism. There is a poor correlation between serologic titer and symptomatology [271]. Detection of the pathogen in blood smear is difficult and frequently requires repeated examinations. The sensitivity of the PCR to detect the organism is higher [272].

Treatment is carried out with atovaquone, azithormycin, and clindamycin, if necessary in combination with quinine.

Following assessment of all data available, it seems that babesiosis - due to the dominant European pathogen, Babesia divergens - does not represent a major health hazard and thus is of little consequence as a co-infection in Lyme disease.

\section{RICKETTSIOSES}

Attention should be directed to the fact that the causative agent of bartonellosis also belongs to the Rickettsia family. In the USA the most important and more frequent rickettsio- sis is the Rocky Mountain Spotted Fever (RMSF), a potentially fatal, but normally curable disease. The clinical picture is primarily characterized by high fever, pronounced malaise, abdominal complaints, and a generalized exanthema. Occasionally, the disease is also linked with CNS manifestations comprising focal neurological deficits and cerebral seizures.

Various different rickettsioses caused by different Rickettsia subspecies are distinguished worldwide. The transmission generally occurs via ticks, but also via mites, fleas, and lice (Table 1). Generalized exanthema - the so-called localized eschar (black wound) - as well as fever, headaches and severe muscle pains are typical symptoms of the disease.

The most important rickettsiosis in Europe is the Mediterranean spotted fever caused by Rickettsia conorii. The disease primarily affects Southern Europe. Chronic courses have not been described in the literature. In the early stage, it does not represent differential diagnostic difficulty with respect to Lyme disease, because of the endemic conditions and the presence of the typical exanthema. Treatment is performed with doxycycline.

\section{TULAREMIA}

Tularemia is caused by the pathogen Francisella tularensis. Transmission occurs via mosquitoes. The disease reservoir comprises many vertebrates.

The main disease manifestations are fever, headaches, malaise, swollen lymph nodes, pharyngitis, eschar (black wound), emesis, pneumonia and the erythematosus papularulcerative lesion at the site of the black spot bite (central eschar, "tache noire").

Relapses can occur, but persistent chronic courses have not been described in the relevant literature. Differential diagnostic problem can occasionally occur with regard to early lyme decrease in cases lacking to crythema migrants.

The treatments of choice are tetracyclines and ciprofloxacin. Betalactamases are inefficient.

\section{Q FEVER}

In contrast to rickettsioses and tularemia, Q fever can exhibit a chronic course. However, There are no significant differential diagnostic problems with regard to Lyme disease. Q fever normally is endemic and as a rule is caused by contact with livestock via inhalation or oral transmission of the pathogen, or by person to person contact. Admittedly, Coxiella burnetii can also be found in other reservoirs, e.g. in ticks (Table 1), but two items are decisive for the diagnosis: the endemic occurrence and the contact with (diseased) livestock and their products (e.g. milk products) and other infected patients.

The decisive diagnosis with regard to a possible $\mathrm{Q}$ fever is thus the occupational activity or the contact with agriculture and livestock. In sporadic cases the frequent consumption of raw milk or the contact with diseased cattle (abort) can be indication of an infection hazard.

Significant disease manifestations include transitory influenza-like clinical picture, pneumonia and hepatitis. Other manifestations comprise erythema, pericarditis and/or 
myocarditis, meningitis, encephalitis [273-275] and myelitis [276, 277].

Q fever can persist for months or years indicative of a chronic course. Chronic endocarditis is the dominant disease manifestation but pericarditis and Guillain-Barré syndrome also occur [278]. The diagnosis is verified by serological tests detecting the presence of specific antibodies.

\section{HUMAN PARVOVIRUS B19 INFECTION}

Human parvovirus B19 infection is transmitted by respiratory tract infection (droplet infection) or during pregnancy and blood transfusion (Table 1). Its reservoir is the human being. The disease can exhibit a chronic course of months or years [279]. Whether parvovirus B19 causes chronic myocarditis and cardiomyopathy is a matter of dispute [280-283]. The chronic course is verified by the detection of pathogen in articular effusions, in the myocardium, bone marrow, and blood [279-285]. With regard to Lyme disease, the following differential diagnostic disease manifestations are relevant: persistent or recurrent arthropathy, myocarditis and cardiomyopathy. Fifth disease or erythema infectiosum is a typical skin manifestation of parvovirus B19 infection in children, but does not normally occur in adults. Arthralgias can last for months or years.

\section{Campylobacter jejuni}

Campylobacter jejuni is a small Gram-negative bacterium whose pathological significance was recognized around 1980. Campylobacter jejuni is among the most frequent pathogens worldwide, causing acute diarrhea. Sources of infection are game and domestic animals, especially poultry, various animal products and contaminated water [286]. The pathogen can persist in a coccoid form, but also in its normal form, for months in unfavorable conditions. It penetrates epithelial cells of the intestine causing their destruction, possibly by means of toxins $[287,288]$.

The main clinical manifestations of Campylobacter jejuni infection are gastroenteritis and abdominal complications in the early phase and reactive arthritis and Guillain-Barré syndrome in the late phase of the disease.

Campylobacter jejuni has differential diagnostic significance due to the late manifestations of the disease, namely due to reactive arthritis and Guillain-Barré syndrome.

Reactive arthritis in Campylobacter jejuni infections is seldom with a frequency of about 2.6\% [289-292]. In connection with a Campylobacter jejuni infection, GuillainBarré syndrome has an unfavorable prognosis [293]. Its incidence is approximately 1\%o [294]. Reactive arthritis occurs approximately one to two weeks after gastroenteritis [288] and Guillain-Barré syndrome approximately two months after the onset of infection [295].

Antibiotic treatment reduces the duration of gastroenteritis. The drugs of choice are erythromycin (1500 mg/daily), azithormycin (500 mg daily) and ciprofloxacin (1000 mg daily). Macrolides [296] and quinolones are primarily recommended, but resistance to them can occur [297]. Resistance to trimethoprim und beta-lactamases also exists [298].

\section{Reactive arthritis}

The term "reactive arthritis" characterizes arthritides, which bear a relationship to certain infectious diseases. In former times the term "Reiter syndrome" was used in cases of concurrent infection of the urethra and the uvea. Arthritis, urethritis and uveitis were termed the Reiter's triad [299,300]. Pathogens, which can induce reactive arthritis include Chlamydia trachomatis, Chlamydia pneumoniae, Yersinia enterocolitica, Salmonellae, Shigella, Campylobacter (usually Campylobacter jejuni), Mycoplasma pneumoniae and possibly Clostridium difficile.

The term "reactive arthritis" is not a defined disease (nosological entity), but rather a concept for the classification of disease relationships with respect to the pathophysiology. The term "reactive arthritis" is problematical. In various infections with reactive arthritis, the pathogens were detected in the synovia and joint fluid. This is true for Chlamydophila pneumoniae [108-110], Chlamydia trachomatis $[125,126]$ and for Yersinia enterocolitica [157,158]. The pathogen was also found in the synovia in cases with arthritis in connection with Mycoplasma pneumoniae [171].

Reactive arthritis occurs days to weeks after the onset of infection. It predominantly affects the joints of the lower extremities. In cases with disease duration of less than 6 months, the term "acute reactive arthritis" was designated and for those with disease duration of more than 6 months, the term "chronic reactive arthritis" is used.

In $50 \%$ of the cases, the joints of the upper extremities are also affected, including the small joints, and the arthritis can be accompanied by tendonitis (enthesitis) [301-304].

One of the most important differential diagnoses of reactive arthritis is Lyme arthritis (chronic Lyme disease, Lyme disease in the late stage, stage III).

Reactive arthritis can be associated with other disease manifestations. These extra-articular symptoms in cases of reactive arthritis include urogenital symptoms, conjunctivitis, uveitis, aphthae, hyperkeratotic skin lesions in the region of the sole of the foot and the palm of the hand, nail changes as in psoriasis and genital lesions, such as balanitis.

In the diagnosis of a "reactive arthritis" anamnestic research is to be performed to determine whether there are indications of one of the above-mentioned infections. Accordingly, the following significant anamnestic considerations are important: Chlamydia trachomatis infection with and without symptoms, enteritis and atypical pneumonia.

Additionally, it should be remembered that arthritides are also found in Chlamydophila pneumoniae und Mycoplasma pneumonia infections and that in Chlamydioses, Yersiniosis and also in cases of Mycoplasma pneumoniae, the pathogen has been detected in the synovial membrane or in the articular effusions, respectively.

Using laboratory diagnostic tests (culture, serology), an existing or previous infection can be detected in $50 \%$ of the cases. Other laboratory tests, particularly inflammation markers, like the erythrocyte sedimentation rate (ESR), the C reactive protein (CRP) and leukocytosis are not relevant in cases of reactive arthritis. With regard to Chlamydia tra- 
chomatis, pathogen detection in a urethral smear or in urine using PCR or NAATs is appropriate.

Chronic courses, i.e. a duration of illness exceeding 6 months, are observed in nearly $20 \%$ of the patients [305].

NSAIDs are used for treatment, but only for pain relief since they have no influence on the disease course or disease duration. In contrast, sulfasalazines [131] and TNF antibodies have certain efficacy. Antibiotic treatment is recommended in cases of acute chlamydiosis with the objective of reducing the frequency of reactive arthritis. However, studies in this direction are needed [306]. In cases of chronic reactive arthritis, the efficiency of antibiotic treatment is a matter of controversy [304,307-312].

\section{SUMMARY OF THE CLINICAL SYMPTOMS AND THE TREATMENT OF LYME DISEASE AND CHRONIC CO-INFECTIONS}

An informative overview of the different disease manifestations of Lyme disease and the significant co-infections is given in Table 10. The overview shows than there is substantial overlap in symptoms in cases of Lyme disease, bartonellosis, Yersinia enterocolitica and Mycoplasma pneumonia infections. Additionally, Chlamydophila pneumoniae also exhibits some overlap in the symptomatology with Lyme disease. Chlamydia trachomatis and Campylobacter jejuni are primarily characterized by reactive arthritis and rarely by Guillain-Barré syndrome. Only in cases with chronic Lyme disease does the antibiotic treatment (Table 11) involve the use of cephalosporins of the $3^{\text {rd }}$ generation and, if necessary, of carbapenems. Otherwise, the focus is generally on tetracyclines, macrolides, to some extent on quinolones, particularly gemifloxacin, all of which, exhibit an intracellular and extracellular efficacy.

\section{CONCLUSION}

At the end of the $20^{\text {th }}$ century, a number of infectious diseases attracted the attention of medical and health policy interests. This is primarily due to the fact these diseases frequently have a chronic course. In Europe and North America, but also in many other areas of the world, these chronic diseases are caused by the following pathogens: Borrelia burgdorferi, Bartonella henselae, Mycoplasma pneumoniae, Chlamydophila pneumoniae, Chlamydia trachomatis, Yersinia enterocolitica. In North America, HGA (Human Granulocytic Anaplasma) and Babesias are also important, whereas infections with these pathogens are a rarity in Europe. In addition, other pathogens discussed in the text are of secondary importance with regard to their frequency of occurrence. Borrelia burgdorferi is transmitted by ticks; in some cases this also applies to Bartonella henselae. The two diseases can also be simultaneously transmitted by tick bites. The remaining pathogens mentioned have other modes of transmission. - Of all the above-mentioned infectious diseases, Lyme borreliosis (Borrelia burgdorferi) is by far the most frequent infectious disease with a chronic course. In addition, this disease (Lyme borreliosis, Lyme disease) is the most thoroughly investigated of all the mentioned infectious diseases. On the basis of the special status of Lyme borreliosis, the other infections have been termed "coinfections" in the literature. Lyme borreliosis can be accompanied by one or more coinfections (double or multiple infections). Coinfections exacerbate the expression of the disease and hinder the therapeutic success. The symptomatology of Lyme borreliosis and the so-called coinfections exhibit high degrees of overlap. A subtle diagnostic analysis is required to account for all of the infectious diseases, which could (possibly) be present. The diagnostic and therapeutic options in cases of chronic infectious diseases are limited. This applies to Lyme borreliosis and even more for the coinfections. No adequate laboratory methods are available to the important Bartonella henselae, coinfection and there are no official guidelines available with regard to its antibiotic treatment. All of the above-mentioned pathogens are capable of intracellular localization; thus, (with the exception of

Table 10. Disease Manifestations of Chronic Lyme Disease and Chronic Co-infections (Overview)

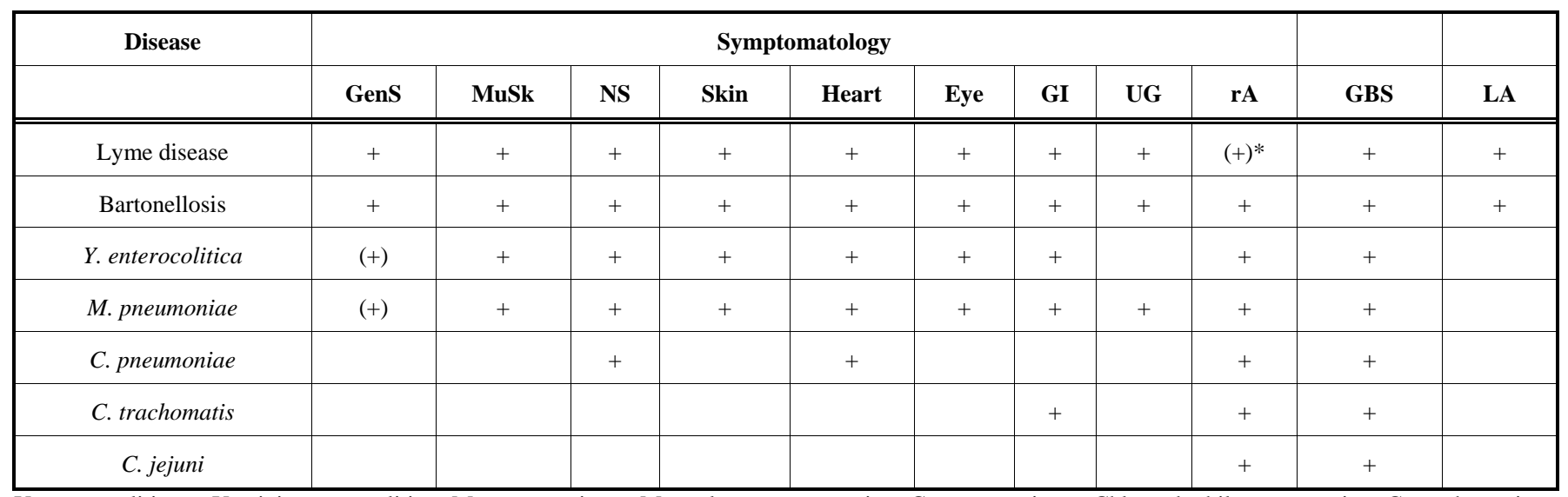

Y. enterocolitica = Yersinia enterocolitica; M. pneumoniae = Mycoplasma pneumoniae; C. pneumoniae = Chlamydophila pneumoniae; C. trachomatis = Chlamydia trachomatis, C. jejuni = Campylobacter jejuni; GenS = general symptoms (fatigue, head aches, lassitude); MuSk = musculoskeletal symptoms (arthritis, arthralgias, myalgias); NS = symptoms of the nervous system (CNS, polyneuropathy, radiculopathy); Skin = skin lesions (erythema migrans, ACA in cases of Lyme disease e.g. infected skin injury); LA = lymphadenopathy; Heart = heart disease (myocarditis, cardiomyopathy, pericarditis); Eye = eye disease (uveitis, conjunctivitis, optic neuritis); GI = gastrointestinal complaints; UG = urogenital symptoms; rA = reactive arthritis; GBS = Guillain-Baré syndrome; + = positive; $(+)$ = presumption based on general symptoms in cases of yersiniosis and Mycoplasma pneumoniae infection; $+^{*}=$ probably chronic infectious, hypothetical autoimmune origin (mimicry). 
Table 11. Antibiotic Treatment of Chronic Lyme Disease and Chronic Co-infections

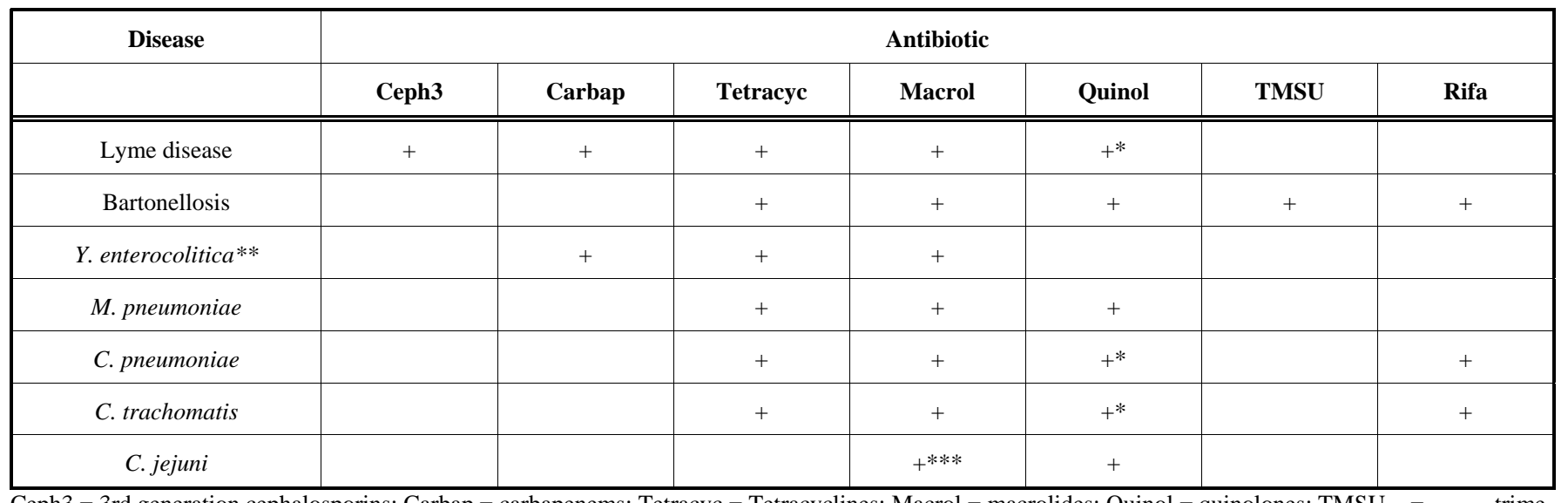

Ceph3 = 3rd generation cephalosporins; Carbap = carbapenems; Tetracyc = Tetracyclines; Macrol = macrolides; Quinol = quinolones; TMSU = thoprim and sulfamethoxazole; Rifa $=$ rifampicin. ${ }^{*}$ Gemifloxacin

* subsequent to testing: Piperacillin

** Ceph3 (if necessary + gentamycin)

*** Erythromycin

Borrelia burgdorferi) only intracellularly acting antibiotics are used. Despite this, the failure rate of the antibiotic treatment of the coinfections is high; on the other hand, with particular regard to Bartonella henselae the opinions on an adequate antibiotic therapy are very controversial. Since the clinical and scientific significance of these chronic infectious diseases has meanwhile been recognized, it is now imperative to develop and improve diagnostic and particularly therapeutic measures for the chronic infectious diseases.

\section{REFERENCES}

[1] Eskow E, Rao RV, Mordechai E. Concurrent infection of the central nervous system by Borrelia burgdorferi and Bartonella henselae:evidence for a noveltick-borne disease complex. Arch Neurol 2001; 58(9): 1357-63.

[2] Grab DJ, Nyarko E, Barat NC, Nikolskaia OV, Dumler JS. Anaplasma phagocytophilum-Borrelia burgdorferi co-infection enhances chemokine, cytokine, and matrix metalloprotease expression by human brainmicrovascular endothelial cells. Clin Vaccine Immunol 2007; 14(11): 1420-4.

[3] Mitchell PD, Reed KD, Hofkes JM.Immunoserologic evidence of co-infectionwith Borreliaburgdorferi, Babesia microti, and human granulocytic Ehrlichia species in residents of Wisconsin and Minnesota. J Clin Microbiol 1996; 34(3): 724-7.

[4] Oleson CV, Sivalingam JJ, O’Neill BJ, Staas WE Jr. Transverse myelitis secondary to coexistent Lyme disease and babesiosis. J Spinal Cord Med 2003; 26(2): 168-71.

[5] Owen DC.Is Lyme disease always poly microbial?--The jigsaw hypothesis. Med Hypotheses 2006; 67(4): 860-4.

[6] Swanson SJ, Neitzel D, Reed KD, Belongia EA. Co-infections acquired from ixodes ticks. Clin Microbiol Rev 2006; 19(4): 70827.

[7] Thomas V, Anguita J, Barthold SW, Fikrig E. Co-infection with Borrelia burgdorferi and the agent of human granulocytic ehrlichiosis alters murine immune responses, pathogen burden, and severity of Lyme arthritis. Infect Immun 2001; 69(5): 3359-71.

[8] Zeidner NS, Dolan MC, Massung R, Piesman J, Fish D. Coinfection with Borrelia burgdorferi and the agent of human granulocytic ehrlichiosissuppresses IL-2 and IFN gamma production and promotes an IL-4 responsein $\mathrm{C} 3 \mathrm{H} / \mathrm{HeJ}$ mice. Parasite Immunol 2000; 22(11): 581-8.

[9] Wormser GP, Nadelman RB, Dattwyler RJ et al. Practice guidelines for the treatment of Lyme disease.The Infectious Diseases Society of America. Clin Infect Dis 2000; 31 (Suppl) 1: 114.
[10] Kristoferitsch W, Stanek G, Kunz C.[Double infection with early summer meningoencephalitis virus and Borrelia burgdorferi. [Article in German]. Dtsch Med Wochenschr 1986; 111(22): 861-4.

[11] Hunfeld K-P. Granulocytic Ehrlichia, Babesia, and spotted fever Rickettsia. Not yet widely known tick-borne pathogens of considerableconcern forhumans at risk in Europe. Biotest Bull 2002; 6: 321-44.

[12] Cadavid D, O’Neill T, Schaefer H, Pachner AR. Localization of Borrelia burgdorferi in the nervous system and other organs in a nonhuman primate model of Lyme disease. Lab Invest 2000; 80(7): 1043-54.

[13] Wormser GP, Dattwyler RJ, Shapiro ED, et al. The clinical assessment, treatment, and prevention of lyme disease, human granulocytic anaplasmosis,and babesiosis:clinical practice guidelines by the Infectious Diseases Societey of America. Clin Infect Dis 2006; 43(9): 1089-134.

[14] Krause PJ, Telford SR $3^{\text {rd }}$, Spielman A, et al. Concurrent Lyme disease and babesiosis.Evidence for increased severity and duration of illness. JAMA 1996; 275(21): 1657-60.

[15] Straubinger RK, Straubinger AF, Summers BA, Jacobson RH. Status of Borrelia burgdorferi infection after antibiotic treatment and the effects of corticosteroids: An experimental study. J Infect Dis 2000; 181(3) : 1069-81.

[16] Stricker RB. Counterpoint:long-term antibiotic therapy improves persistent symptoms associated with lyme disease. Clin Infect Dis 2007; 45(2): 149-57.

[17] Grab DJ, Nyarko E, Barat NC, Nikolskaia OV, Dumler JS. Anaplasma phagocytophilum-Borrelia burgdorferi co-infection enhances chemokine, cytokine, and matrix metalloprotease expression by human brainmicrovascular endothelial cells. Clin Vaccine Immunol 2007; 14(11): 1420-4.

[18] Bass JW, Vincent JM, Person DA.The expanding spectrum of Bartonella infections:II.Cat-scratch disease. Pediatr Infect Dis J 1997; 16(2): 163-79.

[19] Spach DH, Koehler JE. Bartonella-associated infections. Infect Dis Clin North Am 1998; 12(1):137-55.

[20] Wear DJ, Margileth AM, Hadfield TL, Fischer GW, Schlagel CJ, King FM.Cat scratch disease:A bacterial infection. Science 1983; 221(4618): 1403-5.

[21] Rolain JM, Foucault C, Guieu R, La Scola B, Brouqui P, Raoult D. Bartonella quintana in human erythrocytes. Lancet 2002; 360(9328): 226-8.

[22] Englisch CK, Wear DJ, Margileth AM, Lissner CR, Walsh GP. Cat-scratch disease.Isolation and culture of the bacterial agent. JAMA 1988; 259(9): 1347-52.

[23] Schaller DJ. Bartonella Diagnosis and Treatment. Tampa, Florida: Hope Academic Press 2008. 
[24] Thudi KR, Kreikemeier TJ, Phillips NJ, Salvalaggio PR, Kennedy DJ, Hayashi PH. Cat scratch disease causing hepatic masses after liver transplant. Liver Int 2007; 27(1): 145-8.

[25] Bhatti Z, Berenson CS. Adult systemic cat scratch disease associated with therapy for hepatitis C. BMC Infect Dis 2007; 7:8.

[26] Koehler JE, Glaser CA, Tappero JW. Rochalimaea henselae infection.A new zoonosis with the domestic cat as reservoir. JAMA 1994; 271(7): 531-5.

[27] Chomel BB, Abbott RC, Kasten RW, et al. Bartonella henselae prevalence in domestic cats in California:risk factors and association beween bacteremiaand antibody titers. J Clin Microbiol 1995; 33(9): 2445-50.

[28] Bonatti M, Mendez J, Guerrero I, et al. Disseminated Bartonella infection following liver transplantation. Transpl Int 2006; 19(8): 683-7.

[29] Vannier E, Gewurz BE, Krause PJ. Human babesiosis. Infect Dis Clin North Am 2008; 22(3): 469-88.

[30] Zintl A, Mulcahy G, Skerrett HE, Taylor SM, Gray JS. Babesia divergens, a bovine blood parasite of veterinary andzoonotic importance. Clin Microbiol Rev 2003; 16(4): 622-36.

[31] Leiby DA.Babesiosis and blood transfusion:flying under the radar. Vox Sang 2006; 90(3): 157-65.

[32] Fox LM, Wingerter S, Ahmed A, et al. Neonatal babesiosis:case report and review of the literature. Pediatr Infect Dis J 2006; 25(2): 169-73.

[33] Sethi S, Alcid D, Kesarwala H, Tolan RW Jr. Probable congenital babesiosisin infant, new jersey, USA. Emerging Infect Dis 2009; 15(5): 788-91.

[34] von Baehr V. The laboratory diagnostics of the Borrelia infection. Umwelt-Magazin-Gesellschaft 2/2009; 22:119-124.

[35] Moriarty RA, Margileth AM. Cat-scratch disease. Infect Dis Clin North Am 1987; 1(3): 575-90.

[36] Cunningham ET, Koehler JE. Ocular bartonellosis. Am J Ophthalmol 2000; 130(3): 340-9.

[37] Bhatti MT, Asif R, Bhatti LB. Macular star in neuroretinitis. Arch Neurol 2001; 58(6): 1008-9.

[38] Suhler EB, Lauer AK, Rosenbaum JJ. Prevalence of serologic evidence of cat scratch disease in patients with neuroretinitis. Ophthalmology 2000; 107(5): 871-6.

[39] Reed JB, Scales DK, Wong MT, Lattuada CP Jr, Dolan MJ, Schwab IR. Bartonella henselae neuroretinitis in cat scratch disease.Diagnosis,management, and sequelae. Ophthalmology 1998; 105(3): 459-66.

[40] Marra CM. Neurologic complications of Bartonella henselae infection. Curr Opin Neurol 1995; 8(3): 164-9.

[41] Selby G, Walker GL. Cerebral arteritis in cat-scratch disease. Neurology 1979; 29(10): 1413-8.

[42] Baylor P, Garoufi A, Karpathios T, Lutz J, Mogelof J, Moseley D. Transverse myelitis in 2 patients with Bartonella henselaeinfection (cat scratch disease). Clin Infect Dis 2007; 45(4): e42-5.

[43] Maman E, Bickels J, Ephros $\mathrm{M}$, et al. Musculoskeletal manifestations of cat scratch disease. Clin Infect Dis 2007; 45(12): 1535-40.

[44] Giladi M, Maman E, Paran D, et al. Cat-scratch disease-associated arthropathy. Arthritis Rheum 2005; 52(11): 3611-7.

[45] Ben-Ami R, Ephros M, Avidor B, et al. Cat-scratch disease in elderly patients. Clin Infect Dis 2005; 41(7): 969-74.

[46] Spach DH, Kaplan SL. Microbiology, epidemiology, clinical manifestations and diagnosis of cat scratch disease. Up To Date, 2008. Available at: http://www.uptodate.com [Accessed : $20^{\text {th }}$ Sep 2010]

[47] Jensen WA, Fall MZ, Rooney J, Kordick DL, Breitschwerdt EB. Rapididentification and differentiation of Bartonella species using a single-step PCR assay. J Clin Microbiol 2000; 38(5): 1717-22.

[48] Fournier PE, Mainardi JL, Raoult D. Value of microimmunofluorescence for diagnosis and follow-up of Bartonella endocarditis. Clin Diagn Lab Immunol 2002; 9(4): 795-801.

[49] Ridder GJ, Boedeker CC, Technau-Ihling K, Grunow R, Sander A. Role of cat- scratch disease in lymphadenopathy in the head and neck. Clin Infect Dis 2002; 35(6): 643-9.

[50] Gilaldi M, Maman E, Paran D, et al. Cat-scratch disease-associated arthropathy. Arthritis Rheum 2005; 52(11):3611-7.

[51] Ridder GJ, Boedeker CC, Technau-Ihling K. Cat-scratch disease:Otolaryngologic manifestations and management. Otolaryngol Head Neck Surg 2005; 132(3):353-8.
[52] Tsujino K, Tsukahara M, Tsuneoka H, et al. Clinical implication of prolongedfever in children with cat scratch disease. J Infect Chemother 2004; 10(4): 227-33.

[53] Methkor-Cotter E, Kletter Y, Avidor B, et al. Long-term serological analysis and clinical follow-up of patients with cat scratch disease. Clin Infect Dis 2003; 37(9):1149-54.

[54] Murakami K, Tsukahara M, Tsuneoka H, et al. Cat scratch disease: analysis of130 seropositive cases. J Infect Chemother 2002; 8(4): 349-52.

[55] Eskow E, Rao RV, Mordechai E. Concurrent infection of the central nervous system by Borrelia burgdorferi and Bartonella henselae:evidence for a noveltick-borne disease complex. Arch Neurol 2001; 58(9):1357-63.

[56] Dietrich F, Schmidgen T, Maggi RG, et al. Prevalence of Bartonella henselae and Borrelia burgdorferi sensu lato DNA in ixodes ricinus ticks in Europe. Appl Environ Microbiol 2010; 76(5): 13958.

[57] Windsor JJ. Cat-scratch disease:epidemiology, aetiology and treatment. Br J Biomed Sci 2001; 58(2): 101-10.

[58] Guptill L. Bartonellosis. Vet Microbiol 2010; 140(3-4): 357-59.

[59] Cotell SL, Noskin GA. Bacillary angiomatosis.Clinical and histologic features, diagnosis, and treatment. Arch Intern Med 1994; 154(5): 524-8.

[60] Pulliainen AT, Dehio C. Bartonella henselae:subversion of vascularendothelial cell functions by translocated bacterial effector proteins. Int J Biochem Cell Biol 2009; 41(3): 507-10.

[61] Riess T, Andersson SG, Lupus A, et al. Bartonella adhesin mediates a proangiogenic host cell response. J Exp Med 2004; 200(10): 1267-78.

[62] Dehio C, Meyer M, Berger J, Schwarz H, Lanz C. Interaction of Bartonella henselae with endothelial cells results in bacterial aggregation on the cell surface and the subsequent engulfment and internalisation of the bacterialaggregate by a unique structure, the invasome. J Cell Sci 1997; 100(Pt 18): 2141-54.

[63] Kempf VA, Lebiedziejwski M, Alitalo $\mathrm{K}$ et al. Activation of hypoxia-inducible factor-1 in bacillary angiomatosis:evidence for a role of hypoxia-inducible factor-1 in bacterial infections. Circulation 2005; 111(8): 1054-62.

[64] Kirby JE. In vitro model of Bartonella henselae-induced angiogenesis. Infect Immun 2004; 72(12): 7315-7.

[65] Dehio C. Recent progress in understanding Bartonella-induced vascularproliferation. Curr Opin Microbiol 2003; 6(1): 61-5.

[66] Resto-Ruiz S, Burgess A, Anderson BE. The role of the host immuneresponse in pathogenesis of Bartonella henselae. DNA Cell Biol 2003; 22(6): 431-40.

[67] Kempf VA, Volkmann B, Schaller M, et al. Evidence of a leading role for VEGF in Bartonella henselae-induced endothelial cell proliferations. Cell Microbiol 2001; 3(9): 623-32.

[68] Rolain JM, Amoux D, Parzy D, Sampol J, Raoult D. Experimental infection of human erythrocytes from alcoholic patients with Bartonella Quintana. Ann NYAcad Sci 2003; 990: 605-11.

[69] Rolain JM, Foucault C, Guieu R, La Scola B, Brouqui P, Raoult D. Bartonella Quintana in human erythrocytes. Lancet 2002; 360(9328): 226-8.

[70] Mursic VP, Wanner G, Reinhardt S, Wilske B, Busch U, Marget W. Formationand cultivation of Borrelia burgdorferi spheroplast-Lform variants. Infection 1996; 24(3): 218-26.

[71] Liu NY. Randomized trial of doxycycline vs. amoxicillin/probenecid for the treatment of Lyme arthritis:treatment of non responders with iv penicillin or ceftriaxone. Arthritis Rheum 1989; 32: 46.

[72] Kraiczy P, Skerka C, Kirschfink M, Zipfel PF, Brade V. Immune evasion of Borrelia burgdorferi:insufficient killing of the pathogens by complement and antibody. Int J Med Microbiol 2002; 291 (Suppl 33): 141-6.

[73] Kraiczy P, Skerka C, Zipfel PF, Brade V. Complement regulatoracquiring surface proteins of Borrelia burgdorferi:a new protein family involved in complement resistance. Wien Klin Wochenschr 2002; 114(13-14): 568-73.

[74] Mursic VP, Wanner G, Reinhardt S, Wilske B, Busch U, Marget W. Formationand cultivation of Borrelia burgdorferi spheroplast-Lform variants. Infection 1996; 24(3): 218-26.

[75] Brorson O, Brorson SH. An in vitro study of the susceptibility of mobile andcystic forms of Borrelia burgdorferi to hydroxychloroquine. Int Microbiol 2002; 5(1): 25-31. 
[76] Kerkhoff FT, Rothova A. Bartonella henselae associated uveitis and HLA-B27. Br J Ophthalmol 2000; 84(10): 1125-9.

[77] Foucault C, Brouqui P, Raoult D. Bartonella quintana characteristics and clinical management. Emerg Infect Dis 2006; 12(2): 217-23.

[78] Relman DA. Has trench fever returned? N Engl J Med 1995; 332(7): 463-4.

[79] Vinson JW. In vitro cultivation of the rickettsial agent of trench fever. Bull World Health Organ 1966; 35(2): 155-64.

[80] Spach DH, Kanter AS, Dougherty MJ, et al. Bartonella (Rochalimaea) quintana bacteremia in inner-city patients with chronic alcoholism. N Engl J Med 1995; 332(7): 424-8.

[81] Bass JW, Freitas BC, Freitas AD, et al. Prospective randomized double blind placebo-controlled evaluation of azithromycin for treatment of cat-scratch disease. Pediatr Infect Dis J 1998; 17(6): 447-52.

[82] Study Team. Atovaquone plus cholestyramine in patients coinfected with Babesia microti and Borrelia burgdorferi refractory to othertreatment. Adv Ther 2006; 23(1): 1-11.

[83] Chia JK, Nakata MM, Lami JL, Park SS, Ding JC. Azithromycin for the treatment of cat-scratch disease. Clin Infect Dis 1998; 26(1): 193-4.

[84] Arisoy ES, Correa AG, Wagner ML, Kaplan SL. Hepatosplenic cat-scratch disease in children:selected clinical features and treatment. Clin Infect Dis 1999; 28(4): 778-84.

[85] Bogue CW, Wise JD, Gray GF, Edwards KM.Antibiotic therapy for cat-scratch disease? JAMA 1989; 262(6): 813-6.

[86] Foucault C, Raoult D, Brouqui P. Randomized open trial of gentamicin and doxycycline for eradication of Bartonella quintana from blood in patients with chronic bacteremia. Antimicrob Agents Chemother 2003; 47(7): 2204-7.

[87] Raoult D, Fournier PE, Vandenesch F, et al. Outcome and treatment of Bartonella endocarditis. Arch Intern Med 2003; 163(2): 226-30.

[88] Rolain JM, Brouqui P, Koehler JE, Maguina C, Dolan MJ, Raoult D. Recommendations for treatment of human infections caused by Bartonella species. Antimicrob Agents Chemother 2004; 48(6): 1921-33.

[89] Rolain JM, Brouqui P, Koehler JE, Maguina C, Dolan MJ, Raoult D. Minireview. Recommendations for Treatment of Human Infections Caused by Bartonella Species. Antimicrob Agents Chemother 2004; 1921-33.

[90] Pendle S, Ginn A, Iredell J. Antibicrobial susceptibility of Bartonella henselae using Etest methodology. Antimicrob Agents Chemother 2006; 761-63.

[91] Dörbecker C, Sander A, Oberle K, Schülin-Casonato T. In vitro susceptivility of Bartonella species in 17 antimicrobial compounds: comparison of Etest and agar dilution. Antimicrob Agents and Chemotherapy 2006; 784-88.

[92] Florin TA, Zaoutis TE, Zaoutis LB. Beyond cat scratch disease: widening spectrum of Bartonella henselae infektion. Pediatrics 2008; 121; e1413.

[93] Tsuneoka H, Yanagihara M, Nojima J, Ichihara K. Anitmicrobial susceptibility by Etest of Bartonella henselae isolated from cats and human in Japan. J Infect Chemother 2010; 16(6): 446-8

[94] Conrad DA. Treatment of cat-scratch disease. J Curr Opin Pediatr 2001; 13(1): 56-9.

[95] Sander A. Epidemiology, clinic picture und diagnostics of Bartonella infections. Institute for Medical Microbiology and Hygiene of the University of Freiburg. Antibiotika Monitor 2003. vol.3,

[96] Sobraqués M, Maurin M, Birtels RJ, Raoult D. In Vitro Susceptibilities of Four Bartonella bacilliformis Strains to 30 Antibiotic Compounds. Antimicrob Agents Chemother 1999; 43(8): 2090-92.

[97] Rolain JM, Maurin M, Raoult D. Bactericidal effect of antibiotics on Bartonella and Brucella spp.: clinical implications. J Antimicrob Chemother 2000; 46(5):811-4.

[98] Margileth AM. Antibiotic therapy for cat-scratch disease:clinical study of therapeutic outcome in 268 patients and a review of the literature. Pediatr Infect Dis J 1992; 11(6): 474-8.

[99] Musso D, Drancourt M, Raoult D. Lack of bactericidal effect of antibiotics except aminoglycosides on Bartonella (Rochalimaea) henselae. Br Soc Antimicrob Chemother 1995; 36: 101-8.

[100] Biswas S, Maggi RC, Papich MG, Keil D, Breitschwerdt EB. Comparative activity of Pradofloxacin, Enrofloxacin, And Azithromycin against Bartonella henselae isolates collected from cats and a human. J Clin Microbiol 2010; 617-8.
[101] Ives TJ, Manzewitsch P, Regnery RL, Butts JD, Kebede M. In vitro susceptibilities of Bartonella henselae, B. quintana, B. elizabethae, Rickettsia rickettsii, R. conorii, R. akari, and R. prowazekii to macrolide antibiotics as determined by immunofluorescent-antibody analysis of infected Vero cell monolayers. Antimicrob Agents Chemother 1997; 41(3): 578-82.

[102] Musso D, Drancourt M, Raoult D. Lack of bactericidal effect of antibiotics except aminoglycosides on Bartonella (Rochalimaea) henselae. J Antimicrob Chemother 1995; 36(1):101-8.

[103] Kordick DL, Papich MG, Breitschwerdt EB. Efficacy of enrofloxacin or doxycycline for treatment of Bartonella henselae or Bartonella clarridgeiae infection in cats. Antimicrob Agents Chemother 1997; 41(11): 2448-55.

[104] Kordick DL, Papich MG, Breitschwerdt EB. Efficacy of Enrofloxacin or Doxycycline for Treatment of Bartonella henselae or Bartonella clarridgeiae Infection in Cats. Antimicrob Agents Chemother 1997; 41(11): 2448-55.

[105] Madell, GL, Bennett, JE, Dolin, R, Eds. Infectious Diseases 5th ed, Philadelphia: Churchill Livingstone 2000, p. 2007.

[106] Myhra W, Mordhorst CH, Wang SP, et al. Clinical features of Chlamydia pneumoniae, strain TWAR, infection in Denmark 19751987. In: Bowie, WR, Caldwell, HD, Jones, RP (Eds), Chlamydial Infections. Cambridge Univ. Press, NY: 1980, p. 422.

[107] Bourke SJ, Lightfoot NF. Chlamydia pneumoniae:defining the clinicalspectrum of infection requires precise laboratory diagnosis.Thorax 1995; 50(Suppl 1):S43-8.

[108] Carter JD, Espinoza LR, Inman RD, et al. Combination antibiotics as atreatment for chronic Chlamydia-induced reactive arthritis:a double-blind,placebo-controlled, prospective trial.Arthritis Rheum 2010; 62(5): 1298-307.

[109] Gérard HC, Whittum-Hudson JA, Carter JD, Hudson AP.Molecular biology of infectious agents in chronic arthritis.Rheum Dis Clin North Am 2009; 35(1): 1-19.

[110] Carter JD, Gérard HC, Espinoza LR, et al. Chlamydiae as etiologic agents in chronic undifferentiated spondylarthritis.Arthritis Rheum 2009; 60(5): 1311-6.

[111] Fainardi E, Castellazzi M, Tamborino C, et al. Chlamydia pneumoniae-specific intrathecal oligoclonal antibody response is predominantly detected in asubset of multiple sclerosis patients with progressive forms. J Neurovirol 2009; 15(5-6): 425-33.

[112] Appelt DM, Roupas MR, Way DS, et al. Inhibition of apoptosis in neuronal cells infected with Chlamydophila (Chlamydia) pneumoniae.BMC Neurosci 2008; 9: 13.

[113] Contini C, Cultrera R, Seraceni S, Castellazzi M, Granieri E, Fainardi E. Cerebrospinal fluid molecular demonstration of Chlamydia pneumoniae DNAis associated to clinical and brain magnetic resonance imaging activity in a subset of patients with relapsing-remitting multiple sclerosis.Mult Scler 2004; 10(4): 3609.

[114] Gerard HC, Wang Z, Whittum-Hudson JA, et al. Cytokine and chemokine mRNA produced in synovial tissue chronically infected with Chlamydia trachomatis and C. pneumoniae. J Rheumatol 2002; 29(9): 1827-35.

[115] De Backer J, Mak R, De Bacquer D, et al. Parameters of inflammation and infection in a community based case-control study of coronary heart disease. Atherosclerosis 2002; 160(2): 457-63.

[116] Miklossy J, Kasas S, Zum AD, McCall S, Yu S, McGeer PL. Persisting atypical and cystic forms of Borrelia burgdorferi and local inflammation in Lyme neuroborreliosis. J Neuroinflammation 2008; 5: 40.

[117] Almeida OP, Lautenschlager NT.Dementia associated with infectious diseases. Int Psychogeriatr 2005; 17 (Suppl 1):S65-77.

[118] MacDonald AB. Alzheimer's disease Braak Stage progressions: reexamined and redefined as Borrelia infection transmission through neural circuits. Med Hypotheses 2007; 68(5): 1059-64.

[119] Fallon BA, Levin ES, Schweitzer PJ, Hardesty D. Inflammation and central nervous system Lyme disease. Neurobiol Dis 2010; 37(3): 534-41.

[120] Tuuminen T, Palomäki P, Paavonen J. The use of serologic tests for thediagnosis of chlamydial infections. J Microbiol Methods 2000; 42(3): 265-79.

[121] Kumar S, Hammerschlag MR. Acute respiratory infection due to Chlamydia pneumoniae:current status of diagnostic methods. Clin Infect Dis 2007; 44(4): 568-76.

[122] Gaydos CA, Roblin PM, Hammerschlag MR, et al. Diagnostic utility of PCR- enzyme immunoassay, culture, and serology for 
detection of Chlamydia pneumoniae in symptomatic and asymptomatic patients. J Clin Microbiol 1994; 32(4): 903-5.

[123] Vergis EN, Indorf A, File TM Jr, et al. Azithormycin vs cefuroxime plus erythromycin for empiricaltreatment of communityacquired pneumonia in hospitalized patients:a prospective, randomized, multicenter trial. Arch Intern Med 2000; 160(9): 1294300.

[124] Appelbaum PC, Gillespie SH, Burley CJ, Tillotson GS. Antimicrobial selection for community-acquired lower respiratory tract infections in the $21^{\text {st }}$ century:areview of gemifloxacin. Int $\mathrm{J}$ Antimicrob Agents 2004; 23(6): 533-46.

[125] Villareal C, Whittum-Hudson JA, Hudson AP.Persistent Chlamydiae and chronic arthritis. Arthritis Res 2002; 4(1): 5-9.

[126] Beutler AM, Hudson AP, Whittum-Hudson JA, et al. Chlamydia trachomatis Can Persist in Joint Tissue After Antibiotic Treatment in Chronic Reiter'sSyndrome / Reactive Arthritis. J Clin Rheumatol 1997; 3(3): 125-130.

[127] Centers for Disease Control and Prevention, Workowski KA, Berman SM. Sexually transmitted diseases treatment guidelines, 2006. MMWR Recomm Rep 2006; 55(RR-11): 1-94.

[128] Quinn TC, Welsh L, Lentz A, et al. Diagnosis by AMPLICOR PCR of Chlamydia trachomatis infection in urine samples from women and men attending sexually transmitted disease clinics. J Clin Microbiol 1996; 34(6): 1401-6.

[129] Chernesky MA, Lee H, Schachter J, et al. Diagnosis of Chlamydia trachomatis urethral infection insymptomatic and asymptomatic men by testing first-voidurine in a ligase chain reaction assay. $\mathrm{J}$ Infect Dis 1994; 170(5): 1308-11.

[130] Cook RL, Hutchinson SL. Ostergaard L, Braithwaite RS, Ness RB.Systematic review:noninvasive testing for Chlamydia trachomatis and Neisseriagonorrhea. Ann Intern Med 2005; 142(11): 914-25.

[131] Clegg DO, Reda DJ, Weisman MH, et al. Comparison of sulfasalazine and placebo in the treatment of reactive arthritis (Reiter's syndrome). A Department of Veterans Affairs Cooperative Study. Arthritis Rheum 1996; 39(12): 2021-7.

[132] Flagg SD, Meador R, Hsia E, Kitumnuaypong T, Schumacher HR Jr. Decreased pain and synovial inflammation after etanercept therapy in patientswith reactive and undifferentiated arthritis:an open-label trial. Arthritis Rheum 2005; 53(4): 613-7.

[133] Ostroff S. Yersinia as an emerging infection:epidemiologic aspects ofYersiniosis. Contrib Microbiol Immunol 1995; 13: 5-10.

[134] Portnoy DA, Martinez RJ. Role of a plasmid in the pathogenicity of Yersinia species. Curr Top Microbiol Immunol 1985; 118: 29-51.

[135] Iriarte M, Sory MP, Boland A, et al. TyeA, a protein involved in control of Yop release and in translocation of Yersinia Yop effectors. EMBO J 1998; 17(7): 1907-18.

[136] Sarker MR, Sory MP, Boyd AP, Iriarte M, Comelis GR. LcrG is required for efficient translocation of Yersinia Yop effector proteins into eukaryotic cells. Infect Immun 1998; 66(6): 2976-9.

[137] Boland A, Cornelis GR. Role of YopP in suppression of tumor necrosis factoralpha release by macrophages during Yersinia infection. Infect Immun 1998; 66(5): 1878-84.

[138] Tacket CO, Narain JP, Sattin R, et al. A multistate outbreak of infections caused by Yersiniaenterocolitica transmitted by pasteurized milk. JAMA 1984; 251(4): 483-6.

[139] Ostroff SM, Kapperud G, Lassen J, Aasen S, Tauxe RV. Clinical features ofsporadic Yersinia enterocolitica infections in Norway. J Infect Dis 1992; 166(4): 812-7.

[140] Tauxe RV, Vandepitte J, Wauters G, et al. Yersinia enterocolitica infections and pork:the missing link. Lancet 1987; 1(8542): 112932.

[141] Tacket CO, Davis BR, Carter GP, Randolph JF, Cohen ML. Yersinia enterocolitica pharyngitis. Ann Intern Med 1983; 99(1): 40-2.

[142] Cover TL, Aber RC. Yersinia enterocolitica. N Engl J Med 1989; 321(1): 16-24.

[143] Black RE, Slome S. Yersinia enterocolitica. Infect Dis Clin North Am 1988; 2(3): 625-41.

[144] Reed RP, Robins-Browne RM, Williams ML.Yersinia enterocolitica peritonitis. Clin Infect Dis 1997; 25(6): 1468-9.

[145] Blinkhorn RJ Jr, Marino JA. Lateral pharyngeal abscess due to Yersinia enterocolitica. Am J Med 1988; 85(6): 851-2.

[146] Krogstad P, Mendelman PM, Miller VL, et al. Clinical and microbiologic characteristics of cutaneuous infection with Yersinia enterocolitica. J Infect Dis 1992; 165(4): 740-3.
[147] Crowe M, Ashford K, Ispahani P. Clinical features and antibiotic treatment ofseptic arthritis and osteomyelitis due to Yersinia enterocolitica. J Infect Microbiol 1996; 45(4): 302-9.

[148] Kellogg CM, Tarakji EA, Smith M, Brown PD. Bacteremia and suppurative lymphadenitis due to Yersinia enterocolitica in a neutropenic patient who prepared chitterlings.Clin Infect Dis 1995; 21(1): 236-7.

[149] Saebo A, Lassen J. Yersinia enterocolitica:an inducer of chronic inflammation. Int J Tissue React 1994; 16(2): 51-7.

[150] Saebo A, Lassen J. Acute and chronic pancreatic disease associated withYersinia enterocolitica infection:a Norwegian 10-year followup study of 458hospitalized patients. J Intern Med 1992; 231 (5): 537-41.

[151] Saebo A, Lassen J. Acute and chronic gastrointestinal manifestationsassociated with Yersinia enterocolitica infection. A Norwegian 10-year follow-up study on 458 hospitalized patients. Ann Surg 1992; 215(3): 250-5.

[152] Lindholm H, Visakorpi R. Late complications after a Yersinia enterocolitica epidemic:a follow up study. Ann Rheum Dis 1991; 50(10): 694-6.

[153] Saebo A, Lassen J. A survey of acute and chronic disease associated with Yersinia enterocolitica infection. A Norwegian 10year follow-up study on 458 hospitalized patients. Scand J Infect Dis 1991; 23(5): 517-27.

[154] Fordham JN, Maitra S. Post-yersinial arthritis in Cleveland, England. Ann Rheum Dis 1989; 48(2): 139-42.

[155] Saebo A, Vik E, Lange OJ, Matuszkiewicz L. Inflammatory bowel disease associated with Yersinia enterocolitica O:3 infection. Eur J Intern Med 2005; 16(3): 176-82.

[156] van der Heijden IM, Res PC, Wilbrink B, et al. Yersinia enterocolitica: a causeof chronic polyarthritis. Clin Infect Dis 1997; 25(4): 831-7.

[157] Granfors K, Jalkanen S, von Essen R, et al. Yersinia antigens in synovial-fluid cells from patients with reactive arthritis. N Engl J Med 1989; 320(4): 216-21.

[158] Granfors K, Merilahti-Palo R, Luukkainen R, et al. Persistence of Yersinia antigens in peripheral blood cells from patients with Yersinia enterocolitica O:3 infection with or without reactivearthritis. Arthritis Rheum 1998; 41(5): 855-62.

[159] Leirisalo-Repo M, Suoranta H. Ten-year follow-up study of patient with Yersinia arthritis. Arthritis Rheum 1988; 31(4): 533-7.

[160] Braun J, Tuszewski M, Eggens U, et al. Nested polymerase chain reaction strategy simultaneously targeting DNA sequences of multiple bacterial speciesin inflammatory joint diseases. I. Screening of synovial samples of patients with spondyloarthropathies and other arthritides. J Rheumatol 1997; 24(6): 1092-100.

[161] Hoogkamp-Korstanje JA, de Koning J, Heesemann J. Persistence of Yersinia enterocolitica in man.Infection 1988; 16(2): 81-5.

[162] Bottone EJ. Yersinia enterocolitica:the charisma continues.Clin Microbiol Rev 1997; 10(2): 257-76.

[163] Martin RE, Bates JH. Atypical pneumonia. Infect Dis Clin North Am 1991; 5(3): 585-601.

[164] Frydén A, Bengtsson A, Foberg U, et al. Early antibiotic treatment of reactive arthritis associated with enteric infections:clinical and serological study. BMJ 1990; 301(6764): 1299-302.

[165] Mansel JK, Rosenow EC $3^{\text {rd }}$, Smith TF, Martin JW Jr. Mycoplasma pneumoniae pneumonia. Chest 1989; 95(3): 639-46.

[166] Koskiniemi M. CNS manifestations associated with Mycoplasma pneumoniae infections:summary of cases at the University of Helsinki and review. Clin Infect Dis 1993; 17 (Suppl 1):S52-7.

[167] Daxboeck F. Mycplasma pneumoniae central nervous system infections. Curr Opin Neurol 2006; 19(4): 374-8.

[168] Bitnun A, Ford-Jones E, Blaser S, Richardson S. Mycoplasma pneumoniae encephalitis. Semin Pediatr Infect Dis 2003; 14(2): 96107.

[169] Smith R, Eviatar L. Neurologic manifestations of Mycoplasma pneumoniae infections:diverse spectrum of diseases.A report of six cases and review ofthe literature. Clin Pediatr (Phila) 2000; 39(4): 195-201.

[170] Tsiodras S, Kelesidis T, Kelesidis I, Voumbourakis K, Giamarellou H. Mycoplasma pneumoniae-associated myelitis:a comprehensive review. Eur J Neurol 2006; 13(2): 112-24.

[171] Chaudhry R, Nisar N, Malhotra P, Kumar A, Chauhan VS. Polymerase chain reaction confirmed Mycoplasma pneumoniae 
arthritis:a case report. Indian J Pathol Microbiol 2003; 46(3): 4336.

[172] Vitullo BB, O’Regan S, de Chadarevian JP, Kaplan BS. Mycoplasmapneumonia associated with acute glomerulonephritis. Nephron 1978; 21(5): 284-8.

[173] Weinstein O, Shneck M, Levy J, Lifshitz T. Bilateral acute anterior uveitis as a presenting symptom of Mycoplasma pneumoniae infection. Can J Ophthalmol 2006; 41(5): 594-5.

[174] Yashar SS, Yashar B, Epstein E, Viani RM. Uveitis associated withMycoplasma pneumoniae meningitis. Acta Ophthalmol Scand 2001; 79(1): 100-1.

[175] Fusco C, Bonini E, Soncini G, Frattini D, Giovannini S, Della Giustina E. Transient basal ganglia and thalamic involvement following Mycoplasma pneumoniae infection associated with antiganglioside antibodies. J Child Neurol 2010; 25(8): 1029-33.

[176] Ashtekar CS, Jaspan T, Thomas D, Weston V, Gayatri NA, Whitehouse WB.Acute bilateral thalamic necrosis in a child with Mycoplasma pneumoniae. Dev Med Child Neurol 2003; 45(9): 634-7.

[177] Hsing J, Welgampola M, Kieman MC. Reversible myeloradiculopathy due to Mycoplasma pneumoniae. J Clin Neurosci 2007; 14(1): 61-4.

[178] Tsiodras S, Kelesidis I, Kelesidis T, Stamboulis E, Gimarellou H. Central nervous system manifestations of Mycoplasma pneumoniae infections. J Infect 2005; 51(5): 343-54.

[179] Timitilli A, Di Rocco M, Nattero G, Tacchella A, Giacchino R. Unusual manifestations of infections due to Mycoplasma pneumoniae in children. Infez Med 2004; 12(2): 113-7.

[180] Goebels N, Helmchen C, Abele-Horn M, Gasser T, Pfister HW.Extensive myelitis associated with Mycoplasma pneumoniae infection:magneticresonance imaging and clinical long-term follow-up. J Neurol 2001; 248(3): 204-8.

[181] Rabay-Chacar H, Rizkallah E, Hakimeh NI, Khoury L, Merhej MT. Neurological complications associated with Mycoplasma pneumoniae infection.A case report. J Med Liban 2000; 48(2): 108-11.

[182] Abele-Horn M, Franck W, Busch U, Nitschko H, Roos R, Heesemann J. Transverse myelitis associated with Mycoplasma pneumoniae infection. Clin Infect Dis 1998; 26(4): 909-12.

[183] Francis DA, Brown A, Miller DH, Wiles CM, Bennett ED, Leigh N. MRI appearances of the CNS manifestations of Mycoplasma pneumoniae:a reportof two cases. J Neurol 1988; 235(7): 441-3.

[184] MacFarlane PI, Miller V. Transverse myelitis associated with Mycoplasma pneumoniae infection. Arch Dis Child 1984; 59(1): 80-2.

[185] Cotter FE, Bainbridge D, Newland AC. Neurological deficit associated with Mycoplasma pneumoniaereversed by plasma exchange. Br Med J (Clin ResEd) 1983; 286(6358): 22.

[186] Nicholson G. Transverse myelitis complicating Mycoplasma pneumoniae infection. Postgrad Med J 1977; 53(616): 86-7.

[187] Hely MA, Williamson PM, Terenty TR. Neurological complications ofMycoplasma pneumoniae infection. Clin Exp Neurol 1984; 20: 153-60.

[188] Gorthi SP, Kapoor L, Chaudhry R, et al. Guillain-Barré syndrome:associationwith Campylobacter jejuni and Mycoplasma pneumoniae infections in India. Natl Med J India 2006; 19(3): 1379.

[189] Manteau C, Liest JM, Caillon, J et al. Acute severe spinal cord dysfunction in a child with meningitis: Streptococcus pneumoniae and Mycoplasmapneumoniae co-infection.Acta Paediatr 2005; 94(9): 1339-41.

[190] Pfausler B, Engelhardt K, Kampfl A, Spiss H, Tafemer E, Schmutzhard E. Post-infectious central and peripheral nervous system diseases complicatingMycoplasma pneumoniae infection.Report of three cases and review of theliterature. Eur $\mathrm{J}$ Neurol 2002; 9(1): 93-6.

[191] Van Koningsveld R, Van Doom PA, Schmitz PI, Ang CW, Van der Meché FG. Mild forms of Guillain-Barré syndrome in an epidemiologic survey in The Netherlands. Neurology 2000; 54(3): 620-5.

[192] Maida E, Kristoferitsch W. Cerebrospinal fluid findings in mycoplasma pneumoniae infections with neurological complications. Acta Neurol Scand 1982; 65(5): 524-38.

[193] Bayer AS, Galpin JE, Theofilopoulos AN, Guze LB. Neurological disease associated with Mycoplasma pneumoniae pneumonitis: demonstration of viable Mycoplasma pneumoniaein cerebrospinal fluid and blood byradioisotopic and immunofluorescent tissueculture techniques. Ann Intern Med 1981; 94(1): 15-20.

[194] Socan M, Ravnik I, Bencina D, Dovc P, Zakotnik B, Jazbec J. Neurological symptoms in patients whose cerebrospinal fluid is culture- and/or polymerasechain reaction-positive for Mycoplasma pneumoniae. Clin Infect Dis 2001; 32(2): E31-5.

[195] Dionisio D, Valassina M, Mata S, et al. Encephalitis caused directly by Mycoplasma pneumoniae. Scand J Infect Dis 1999; 31(5): 506-9.

[196] Narita M, Matsuzono Y, Itakura O, Togashi T, Kikuta H. Survey ofmycoplasmal bacteremia detected in children by polymerase chain reaction. Clin Infect Dis 1996; 23(3): 522-5.

[197] Thomas NH, Collins JE, Robb SA, Robinson RO. Mycoplasma pneumoniae infection and neurologicaldisease. Arch Dis Child 1993; 69(5): 573-6.

[198] Carstensen H, Nilsson KO. Neurological complications associated withMycoplasma pneumoniae infection in children.Neuropediatrics 1987; 18(1): 57-8.

[199] Foy HM, Nolan CM, Allan ID. Epidemiologic aspects of $\mathrm{M}$. pneumoniae disease complications:a review. Yale J Biol Med 1983; 56(5-6): 469-73.

[200] Mardh PA, Ursing B, Lind K. Persistent cerebellar symptoms after infectionwith Mycoplasma pneumoniae. Scand J Infect Dis 1975; 7(2): 157-60.

[201] Trad S, Ghosn J, Dormont D, Stankoff B, Bricaire F, Caumes E. Nuclear bilateral Bell's palsy and ageusia associated with Mycoplasma pneumoniaepulmonary infection. J Med Microbiol 2005; 54(Pt4): 417-9.

[202] Völter C, Helms J, Weissbrich B, Rieckmann P, Abele-Horn M. Frequent detection of Mycoplasma pneumoniae in Bell's palsy. Eur Arch Otorhinolaryngol 2004; 261(7): 400-4.

[203] Koskiniemi M. CNS manifestations associated with Mycoplasma pneumoniae infections:summary of cases at the University of Helsinki and review. Clin Infect Dis 1993; 17 (Suppl) 1:S52-7.

[204] Assaad F, Gispen R, Kleemola M, Syrucek L, Esteves K. Neurologicaldiseases associated with viral and Mycoplasma pneumoniae infections. Bull World Health Organ 1980; 58(2): 297311.

[205] Lind K, Zoffmann H, Larsen SO, Jessen O. Mycoplasma pneumoniaeinfection associated with affection of the central nervous system. Acta Med Scnad 1979; 205(4): 325-32.

[206] Fink CG, Sillis M, Read SJ, Butler L, Pike M. Neurological disease associatedwith Mycoplasma pneumoniae infection. PCR evidence against a directinvasive mechanism. Clin Mol Pathol 1995; 48(1): M51-4.

[207] Di Maria A, Ruberto G, Redaelli C, Gualtieri G. Anterior uveitis associated with Mycoplasma pneumoniaepneumonia:a case report. Acta Ophthalmol Scand 1999; 77(3): 349-50.

[208] Said MH, Layani MP, Colon S, Faraji G, Gilastre C, Cochat P. Mycoplasma pneumoniae-associated nephritis in children. Pediatr Nephrol 1999; 13(1): 39-44.

[209] Schonwald S, Gunjaca M, Kolacny-Babic L, Car V, Gosev M. Comparison of azithromycin and erythromycin in the treatment of atypical pneumonias. J Antimocrob Chemother 1990; 25 (Suppl) A: $123-6$.

[210] File TM Jr, Segreti J, Dunbar L, et al. A mulicenter, randomized study comparing the efficacy and safety of intravenous and/or oral levofloxacinversus ceftriaxone and/or cefuroxime axetil in treatment of adults withcommunity-acquired pneumonia. Antimicrob Agents Chemother 1997; 41(9): 1965-72.

[211] Maeda K, Markowitz N, Hawley RC, Ristic M, Cox D, McDade JE.Human infection with Ehrlichia canis, a leukocytic rickettsia. N Engl J Med 1987; 316(14): 853-6.

[212] Chen SM, Dumler JS, Bakken JS, Walker DH. Identification of a granulocytotropic Ehrlichia species as the etiologic agent of human disease. J Clin Microbiol 1994; 32(3): 589-95.

[213] Nadelman RB, Horowitz HW, Hsieh TC, et al. Simultaneous humangranulocytic ehrlichiosis and Lyme borreliosis. N Engl J Med 1997; 337(1): 27-30.

[214] Schwartz I, Fish D, Daniels TJ.Prevalence of the rickettsial agent of human granulocytic ehrlichiosis in ticks from a hyperendemic focus of Lyme disease. N Engl J Med 1997; 337(1): 49-50.

[215] Horowitz HW, Kilchevsky E, Haber S, et al. Perinatal transmission of the agent of human granulocytic ehrlichiosis. N Engl J Med 1998; 339(6): 375-8. 
[216] Bakken JS, Dumler S. Human granulocytic anaplasmosis. Infect Dis Clin North Am 2008; 22(3): 433-48.

[217] Bakken JS, Krueth JK, Lund T, Malkovitch D, Asanovich K, Dumler JS. Exposure to deer blood may be a cause of human granulocytic ehrlichiosis. Clin Infect Dis 1996; 23(1): 198.

[218] Krause PJ, Wormser GP.Nosocomial transmission of human granulocytic anaplasmosis?JAMA 2008; 300(19): 2308-9.

[219] Levin ML, Fish D. Acquisition of co-infection and simultaneous transmission of Borrelia burgdorferi and Ehrlichia phagocytophila by Ixodes scapularis ticks. Infect Immun 2000; 68(4): 2183-6.

[220] Maeda K, Markowitz N, Hawley RC, Ristic M, Cox D, McDade JE.Humaninfection with Ehrlichia canis, a leukocytic rickettsia. N Engl J Med 1987; 316(14): 853-6.

[221] Chen SM, Dumler JS, Bakken JS, Walkder DH. Identification of agranulocytotrophic ehrlichia species as the etiologic agent of human disease. J Clin Microbiol 1994; 32(3): 589-95.

[222] Demma LJ, Holman RC, McQuiston JH, Krebs JW, Swerdlow DL.Epidemiology of human ehrlichiosis and anaplasmosis in the United States, 2001-2001. Am J Trop Med Hyg 2005; 73(2): 400-9.

[223] Björsdorff A, Wittesjö B, Berglun J, Massung RF, Eliasson I. Humangranulocytic ehrlichiosis as a common cause of tickassociated fever in Southeast Sweden:report from a prospective clinical study. Scand J Infect Dis 2002; 34(3): 187-91.

[224] Stanczak J, Gabre RM, Kruminis-Lozowska W, Racewicz M, Kubica-Biemat B. Ixodes ricinus as a vector of Borrelia burgdorferi sensu lato, Anaplasma phagocytophilum and Babesia microti in urban and suburban forests. Ann Agric Environ Med 2004; 11(1): 109-14.

[225] Fingerle V, Munderloh UG, Liegl G, Wilske B. Coexistence of ehrlichiae of the phagocytophila group with Borrelia burgdorferi in Ixodes ricinus from Southern Germany. Med Microbiol Immunol 1999; 188(3): 145-9.

[226] Oehme R, Hartelt K, Backe H, Brockmann S, Kimming P. Foci of tick-borne diseases in southwest Germany. Int J Med Microbiol 2002; 291 (Suppl) 33: 22-9.

[227] Schouls LM, Van De Pol I, Rijpkema SG, Schot CS. Detection andidentification of Ehrlichia, Borrelia burgdorferisensu lato, and Bartonellaspecies in Dutch Ixodes ricinus ticks. J Clin Microbiol 1999; 37(7): 2215-22.

[228] Baumgarten B, Harrer TH, Röllinghoff M, Bogdan C. Prevalence of human granulocytic Ehrlichiosis in Ixodes ticks from Southern Germany:Evidence for genetic heterogenety.VIII International Conference on Lyme disease and other Emerging Tick-Borne Diseases, Munich, 1999 (abstract).

[229] Hildebrandt A, Schmidt KH, Wilske B, Dom W, Straube E, Fingerle V. Prevalence of four species of Borrelia burgdorferi sensu lato and co-infection with Anaplasma phagocytophila in Ixodes ricinus ticks in central Germay. Eur J Clin Microbiol Infect Dis 2003; 22(6): 364-7.

[230] Schauber EM, Gertz SJ, Maple WT, Ostfeld RS.Co-infection of blackleggedticks (Acari:Ixodidae) in Dutchess County, New York, with the agents of Lymedisease and human granulocytic ehrlichiosis. J Med Entomol 1998; 35(5): 901-3.

[231] Schwartz I, Fish D, Daniels TJ. Prevalence of the rickettsial agent of human granulocytic ehrlichiosis in ticks from a hyperendemic focus of Lyme disease. N Engl J Med 1997; 337(1): 49-50.

[232] Bakken JS, Krueth J, Tilden RL, Dumler JS, Kristiansen BE. Serological evidence of human granulocytic ehrlichiosis in Norway. Eur J Microbiol Infect Dis 1996; 15(10): 829-32.

[233] Hermanowska-Szpakowicz T, Skotarczak B, Kondrusik M, et al. Detecting DNAs of Anaplasma phagocytophilum and Babesia in the blood of patients suspected of Lyme- disease. Ann Agric Environ Med 2004; 11(2): 351-4.

[234] Pusterla N, Weber R, Wolfensberger C, et al. Serological evidence of human granulocytic ehrlichiosis in Switzerland. Eur J Clin Microbiol Infect Dis 1998; 17(3): 207-9.

[235] Magnarelli LA, Dumler JS, Anderson JF, Johnson RC, Fikring E. Coexistenceof antibodies to tick-borne pathogenes of babesiosis, ehrlichiosis, and Lymeborreliosis in human sera. J Clin Microbiol 1995; 33(11): 3054-7.

[236] Bakken JS, Dumler S. Human granulocytic anaplasmosis. Infect Dis Clin North Am 2008; 22(3): 433-48.

[237] Roland WE, McDonald G, Caldwell CW, Everett ED. Ehrlichiosis - a cause of prolonged fever. Clin Infect Dis 1995; 20(4): 821-5.
[238] Aguero-Rosenfeld ME, Horowitz HW, Wormser GP, et al. Human granulocytic ehrlichiosis:A case series from a medical center in New York State. Ann Intern Med 1996; 125(11): 904-8.

[239] Bakken JS, Dumler JS. Clinical diagnosis and treatment of human granulocytotropic anaplasmosis. Ann N Y Acad Sci 2006; 1078: 236-47.

[240] Dumler JS, Bakken JS. Ehrlichial diseases of humans:emerging tick-borne infections. Clin Infect Dis 1995; 20(5): 1102-10.

[241] Dawson JE, Fishbein DB, Eng TR, Redus MA, Green NR. Diagnosis of human ehrlichiosis with the indirect fluorescentantibody test:kinetics and specificity. J Infect Dis 1990; 162(1): 91-5.

[242] Brouqui P, Bacellar F, Baranton G, et al. Guidelines for the diagnosis of tick-borne bacterial diseases in Europe. Clin Microbiol Infect 2004; 10(12): 1108-32.

[243] Bakken JS, Haller I, Riddell D, Walls JJ, Dumler JS. The serological responseof patients infected with the agent of human granulocytic ehrlichiosis. Clin Infect Dis 2002; 34(1): 22-7.

[244] Bakken JS, Dumler JS. Ehrlichiosis and anaplasmosis. Infect Med 2004; 21:433.

[245] Paddock CD, Childs JE. Ehrlichia chaffeensis:a prototypical emergingpathogen. Clin Microbiol Rev 2003; 16(1): 37-64.

[246] Bakken JS, Krueth J, Wilson-Nordskog C, Tilden RL, Asanovich K, Dumler JS. Clinical and laboratory characteristics of human granulocytic ehrlichiosis. JAMA 1996; 275(3): 199-205.

[247] Bakken JS, Aguero-Rosenfeld ME, Tilden RL, et al. Serial measurements of hematologic counts during the active phase of human granulocyticehrlichiosis. Clin Infect Dis 2001; 32(6): 86270 .

[248] Chapman AS, Bakken JS, Folk SM, et al. Diagnosis and management oftickborne rickettsial diseases:Rocky Mountain spotted fever, ehrlichiosis, andanaplasmosis - United States:a pracitcal guide for physicians and otherhealth-care and public health professionals. MMWR Recomm Rep 2006; 55(RR-4): 1-27.

[249] Standaert SM, Yu T, Scott MA, et al. Primary isolation of Ehrlichia chaffeensis from patients with febrile illnesses:clinical and molecular characteristics. J Infect Dis 2000; 181(3): 1082-8.

[250] Felek S, Unver A, Stich RW, Rikihisa Y. Sensitive detection of Ehrlichia chaffeensis in cell culture, blood, and tick specimens by reverse transcription-PCR. J Clin Microbiol 2001; 39(2): 460-3.

[251] Walls JJ, Caturegli P, Bakken JS, Asanovich KM, Dumler JS. Improvedsensitivity of PCR for diagnosis of human granulocytic ehrlichiosis usingepank1 genes of Ehrlichia phagocytophila-group ehrlichiae. J Clin Microbiol 2000; 38(1): 354-6.

[252] Meer-Scherrer L, Adelson M, Mordechai E, Lottaz B, Tilton R. Babesia microti infection in Europe. Curr Microbiol 1996; 48(6): 435-7.

[253] Mitchell PD, Reed KD, Hofkes JM. Immunoserologic evidence of co-infectionwith Borreliaburgdorferi, Babesia microti, and human granulocytic Ehrlichia species in residents of Wisconsin and Minnesota. J Clin Microbiol 1996; 34(3): 724-7.

[254] Oleson CV, Sivalingam JJ, O’Neill BJ, Staas WE Jr. Transverse myelitis secondary to coexistent Lyme disease and babesiosis. $\mathrm{J}$ Spinal Cord Med 2003; 26(2): 168-71.

[255] Shoemaker RC, Hudnell HK, House DE, Van Kempen A, Pakes GE,COL40155 Study Team. Atovaquone plus cholestyramine in patients coinfected with Babesia microti and Borrelia burgdorferi refractory to othertreatment. Adv Ther 2006; 23(1): 1-11.

[256] Skotarczak B, Wodecka B, Cichocka A. Coexistence DNA of Borreliaburgdorferi sensu lato and Babesia microti in Ixodes ricinus ticks from north- western Poland. Ann Agric Environ Med 2002; 9(1): 25-8.

[257] Skotarczak B, Rymaszewska A, Wodecka B, Sawczuk M. Molecular evidenceof co-infection of Borrelia burgdorferi sensu lato, human granulocyticehrlichiosis agent, and Babesia microti in ticks from northwestern Poland. J Parasitol 2003; 89(1): 194-6.

[258] Halos L, Jamal T, Maillard R, et al. Evidence of Bartonella sp. in questing adult and nymphal Ixodes ricinus ticks from France and co-infection with Borrelia burgdorferi sensu lato and Babesia sp.Vet Res 2005; 36(1): 79-87.

[259] Schwartz I, Fish D, Daniels TJ. Prevalence of the rickettsial agent of human granulocytic ehrlichiosis in ticks from a hyperendemic focus of Lyme disease. N Engl J Med 1997; 337(1): 49-50.

[260] Hermanowska-Szpakowicz T, Skotarczak B, Kondrusik M, et al. Detecting DNAs of Anaplasma phagocytophilum and Babesia in the blood of patients suspected of Lyme disease. Ann Agric Environ Med 2004; 11(2): 351-4. 
[261] Arnez M, Luznik-Bufon T, Avsic-Zupanc T, et al. Causes of febrile illness after a tick bite in Slovenian children. Pediatr Infect Dis 2003; 22(12): 1078-83.

[262] Stricker RB, Gaito A, Harris NS, Burrascano JJ. Co-infection in patients withlyme disease:how big a risk? Clin Infect Dis 2003; 37(9): 1277-8.

[263] Krause PJ, Telford SR $3^{\text {rd }}$, Spielman A, et al. Concurrent Lyme disease and babesiosis. JAMA 1996; 275(21): 1657-60.

[264] Wang TJ, Liang MH, Shangha O, et al. Coexposure to Borrelia burgdorferi and Babesia microti does not worsen the long-term outcome of lyme disease. Clin Infect Dis 2000; 31(5): 1149-54.

[265] Krause PJ, McKay K, Thompson CA, et al. Disease-specific diagnosis of coinfecting tickborne zoonosis:babesiosis, human granulocytic ehrlichiosis,and Lyme disease. Clin Infect Dis 2002; 34(9): 1184-91.

[266] Hatcher JC, Greenberg PD, Antique J, Jimenez-Lucho VE.Severe babesiosisin Long Island:review of 34 cases and their complications. Clin Infect Dis 2001; 32(8): 1117-25.

[267] Krause PJ, Telford SR $3^{\text {rd }}$, Spielman A, et al. Concurrent Lyme disease and babesiosis.Evidence for increased severity and duration of illness. JAMA 1996; 275(21): 1657-60.

[268] Reubush TK $2^{\text {nd }}$, Cassaday PB, Marsh HJ, et al. Human babesiosis on Nantucket Island.Clinical features. Ann Intern Med 1977; 86(1): 6-9.

[269] White DJ, Talarico J, Chang HG, Birkhead GS, Heimberger T, Morse DL. Human babesiosis in New York State:Review of 139 hospitalized cases and analysis of prognostic factors. Arch Intern Med 1998; 158(19): 2149-54.

[270] Krause PJ, Ryan R, Telford S $3^{\text {rd }}$, Persing D, Spielman A. Efficacy of immunoglogulin $\mathrm{M}$ serodiagnostic test for rapid diagnosis of acute babesiosis. J Clin Microbiol 1996; 34(8): 2014-6.

[271] Krause PJ, Telford SR $3^{\text {rd }}$, Ryan R, et al. Diagnosis of babesiosis: evaluationof a serologic test for the detection of Babesia microti antibody. J Infect Dis 1994; 169(4): 923-6.

[272] Vannier E, Gewurz BE, Krause PJ, et al. Human babesiosis, Infect Dis Clin North Am 2008; 22: 469.

[273] Shaked Y, Samra Y. Q fever meningoencephalitis associated with bilateral abducens nerve paralysis, bilateral optic neuritis and abnormal cerebrospinal fluid findings. Infection 1989; 17(6): 3945.

[274] Brooks RG, Licitra CM, Peacock MG. Encephalitis caused by Coxiella burnetii. Ann Neurol 1986; 20(1): 91-3.

[275] Kofteridis DP, Mazokopakis EE, Tselentis Y, Gikas A. Neurological complications of acute Q fever infection. Eur J Epidemiol 2004; 19(11): 1051-4.

[276] Walid MS, Ajjan M, Ulm AJ.Subacute Transverse myelitis with Lyme profile dissociation.Ger Med Sci 2008; 6:Doc04.

[277] Bernit E, Pouget J, Janbon F et al. Neurological involvement in acute $\mathrm{Q}$ fever:a report of 29 cases and review of the literature.Arch Intern Med 2002; 162(6): 693-700.

[278] Bonetti B, Monaco S, Ferrari S, Tezzon F, Rizzuto N. Demyelinating polyradiculoneuritis following Coxiella burnetti infection (Q fever). Ital J Neurol Sci 1991; 12(4): 415-7.

[279] Nikkari S, Roivainen A, Hannonen P, et al. Persistence of parvovirus B19 in synovial fluid and bone marrow. Ann Rheum Dis 1995; 54(7): 597-600.

[280] Kühl U, Pauschinger M, Seeberg B, et al. Viral persistence in the myocardium is associated with progressive cardiac dysfunction. Circulation 2005; 112(13): 1965-70.

[281] Tschöpe C, Bock CT, Kasner M, et al. High prevalence of cardiac parvovirus B19 infection in patients with isolated left ventricular diastolic dysfunction. Circulation 2005; 111(7): 879-86.

[282] Donoso Mantke O, Nitsche A, Meyer R, Klingel K, Niedrig M. Analysing myocardial tissue from explanted hearts of heart transplant recipients and multi-organ donors for the presence of parvovirus B19 DNA. J Clin Virol 2004; 31(1): 32-9.

[283] Schenk T, Enders M, Pollak S, Hahn R, Huzly D. High prevalence of human parvovirus B19 DNA in myocardial autopsy samples from subjects without myocarditis or dilative cardiomyopathy. J Clin Microbiol 2009; 47(1): 106-10.

[284] Lindblom A , Isa A, Norbeck O, et al. Slow clearance of human parvovirus B19 viremia following acute infection. Clin Infect Dis 2005; 41(8): 1201-3.

[285] Lowry SM, Brent LH, Menaldino S, Kerr JR. A case of persistent parvovirusB19 infection with bilateral cartilaginous and ligamentous damage to thewrists. Clin Infect Dis 2005; 41(4):e424.

[286] Friedman CR, Neimann J, Wegener HC, Tauxe RV. Epidemiology of Campylobacter jejuni infections in the United States and other industrialized nations.In: Nachamkin I, Campylobacter, $2^{\text {nd }}$ ed, Blaser MJ, Eds, Washington DC: ASM Press 2000; p. 121.

[287] Whitehouse CA, Balbo PB, Pesci EC, Cottle DL, Mirabito PM, Pickett CL. Campylobacter jejuni cytolethal distending toxin causes a G2-phase cell cycle block. Infect Immun 1998; 66(5): 1934-40.

[288] Pickett CL, Pesci EC, Cottle DL, Russell G, Erdam AN, Zeytin H. Prevalence of cytolethal distending toxin production in Campylobacter jejuni and relatedness of Campylobacter sp. cdtB gene. Infect Immun 1996; 64(6): 2070-8.

[289] Skirrow MB, Blaser MJ.Campylobacter jejuni. In: Blaser, MJ, Smith, PD, Ravdin, JI, et al Eds. I nfections of the gastrointestinal tract, $2^{\text {nd }}$ ed, Philadelphia: 2002; Lippincott Williams and Wilkens, p. 719.

[290] Hannu T, Kauppi M, Tuomala M, Laaksonen I, Klemets P, Kuusi M. Reactive arthritis following an outbreak of Campylobacter jejuni infection. J Rheumatol 2004; 31(3): 528-30.

[291] Garg AX, Pope JE, Thiessen-Philbrook H, Clark WF, Ouimet J. Walkerton Health Study Investigators. Arthritis risk after acute bacterial gastroenteritis. Rheumatology (Oxford) 2008; 47(2): 2004.

[292] Townes JM, Deodhar AA, Laines ES, et al. Reactive arthritis following culture-confirmed infections with bacterial enteric pathogens in Minnesota and Oregon:a population-based study. Ann Rheum Dis 2008; 67(12): 1689-96.

[293] Shenker BJ, Besack D, McKay T, Pankoski L, Zekavat A, Demuth DR. Induction of cell cycle arrest in lymphocytes by Actinobacillus actinomycetemcomitans cytolethal distending toxin requires three subunits for maximum activity. J Immunol 2005; 174(4): 2228-34.

[294] Sorvillo FJ, Lieb LE, Waterman SH.Incidence of campylobacteriosis among patients with AIDS in Los Angeles County.J Acquir Immune Defic Syndr 1991; 4(6): 598-602.

[295] Melamed I, Bujanover Y, Igra YS, Schwartz D, Zakuth V, Spirer Z. Campylobacter enteritis in normal and immunodeficient children. Am J Dis Child 1983; 137(8): 752-3.

[296] Taylor DE, Chang N. In vitro susceptibilities of Campylobacter jejuni and Campylobacter coli to azithromycin and erythromycin. Animicrob Agents Chemother 1991; 35(9): 1917-8.

[297] Gaunt PD, Piddock LJ. Ciprofloxacin resistant Campylobacter spp. in humans:an epidemiological and laboratory study. J Antimicrob Chemother 1996; 37(4): 747-57.

[298] Lariviere LA, Gaudreau CL, Turgeon FF. Susceptibility of clinical isolates of Campylobacter jejuni to twenty-five antimicrobila agents. J Antimicrob Chemother 1986; 18(6): 681-5.

[299] Ahvonen P, Sievers K, Aho K. Arthritis associated with Yersinia enterocolitica infection. Acta Rheumatol Scand 1969; 15(3): 23253.

[300] Panush RS, Wallace DJ, Dorff RE, Engleman EP.Retraction of the suggestion to use the term "Reiter's syndrome" sixty-five years later:the legacy of Reiter, a war criminal, should not be eponymic honor but rather condemnation. Arthritis Rheum 2007; 56(2): 6934.

[301] Keynan Y, Rimar D. Reactive arthritis - the appropriate name.Isr Med Assoc J 2008; 10(4): 256-8.

[302] Hannu T, Inman R, Granfors K, Leirisalo-Repo M. Reactive arthritis or post-infectious arthritis?Best Pract Res Clin Rheumatol 2006; 20(3): 419-33.

[303] Braun J, Kingsley G, van der Hejide D, Sieper J. On the difficulties ofestablishing a consensus on the definition of and diagnostic investigations forreactive arthritis.Results and discussion of a questionnaire prepared for the $4^{\text {th }}$ International Workshop on Reactive Arthritis, Berlin, Germany, July 3-6, 1999. J Rheumatol 2000; 27(9): 2185-92.

[304] Leirisalo-Repo M. Reactive arthritis. Scand J Rheumatol 2005; 34(4): 251-9.

[305] Leirisalo-Repo M, Sieper J. Reactive arthritis: epidemiology, clinical features and treatment In: Weisman MH, van der Heijde D, Reveille JD, Eds. Ankylosing spondylitis and thespondyloarthropathies. Philadelphia: Mosby Elevier 2006; pp. 53-64.

[306] Yu DT,Pathogenesis of reactive arthritis. Intern Med 1999; 38(2): 97-101. 
[307] Kvien TK, Gaston JS, Bardin T, et al. Three month treatment of reactive arthritis with azithromycin:a EULAR double blind, placebo controlled study. Ann Rheum Dis 2004; 63(9): 1113-9.

[308] Yli-Kerttula T, Luukkainen R, Yli-Kerttula U, et al. Effect of a three month course of ciprofloxacin on the late prognosis of reactive arthritis. Ann Rheum Dis 2003; 62(9): 880-4.

[309] Lauhio A, Leirisalo-Repo M, Lähdevirta J, Saikku P, Repo H. Double-blind, placebo-controlled study of three-month treatment with lymecycline in reactive arthritis, with special reference to Chlamydia arthritis. Arthritis Rheum 1991; 34(1): 6-14.
[310] Yli-Kerttula T, Luukkainen R, Yli-Kerttula U, et al. Effect of a three month course of ciprofloxacin on the outcome of reactive arthritis. Ann Rheum Dis 2000; 59(7): 565-70.

[311] Laasila N, Laasonen L, Leirisalo-Repo M. Antibiotic treatment and long term prognosis of reactive arthritis. Ann Rheum Dis 2003; 62(7): 655-8.

[312] Putschky N, Pott HG, Kuipers JG, Zeidler H, Hammer M, Wollenhaupt J. Comparing 10-day and 4-month doxycycline courses for treatment of Chlamydia trachomatis-reactive arthritis:a prospective, double-blind trial. Ann Rheum Dis 2006; 65(11): $1521-4$

Received: April 28, 2012

Revised: June 22, 2012

Accepted: July 02, 2012

(C) Walter Berghoff; Licensee Bentham Open.

This is an open access article licensed under the terms of the Creative Commons Attribution Non-Commercial License (http://creativecommons.org/licenses/by-nc/3.0/) which permits unrestricted, non-commercial use, distribution and reproduction in any medium, provided the work is properly cited. 